\title{
Environmental Assessment of Ground Water Compliance at the Naturita, Colorado, UMTRA Project Site
}

April 2003

\author{
Prepared by \\ U.S. Department of Energy \\ Grand Junction Office \\ Grand Junction, Colorado
}

Work Performed Under DOE Contract No. DE-AC13-02GJ79491 
This page intentionally left blank 


\section{Contents}

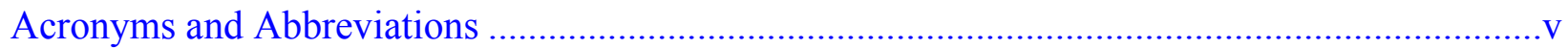

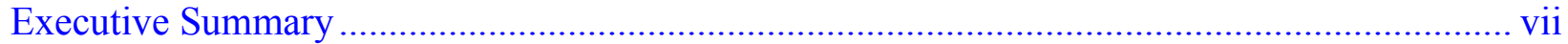

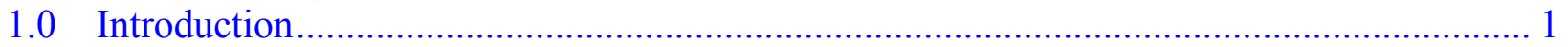

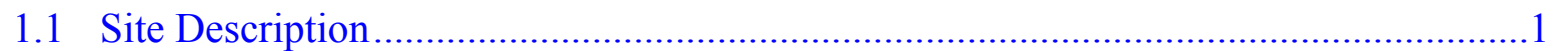

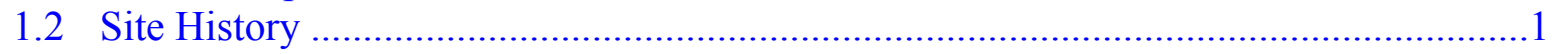

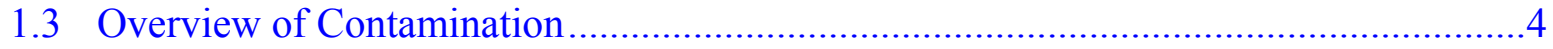

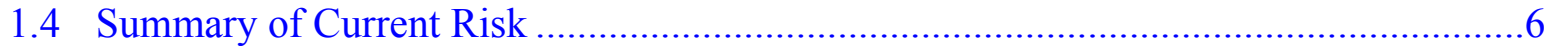

1.5 National Environmental Policy Act Process ............................................................6

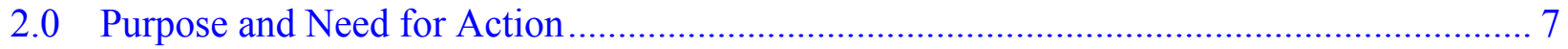

3.0 Proposed Action and No Action Alternatives.................................................................... 7

3.1 Proposed Action Alternative ..................................................................................

3.1.1 Decision Process for the Proposed Action .....................................................

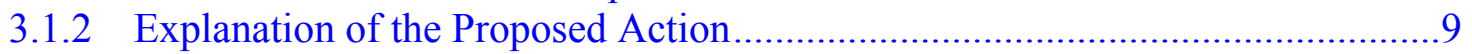

3.1.2.1 Alternate Concentration Limits............................................................

3.1.2.2 Institutional Controls ......................................................................12

3.1.2.3 Monitoring Plan ..............................................................................12

3.1.3 Alternatives Considered but Eliminated...................................................13

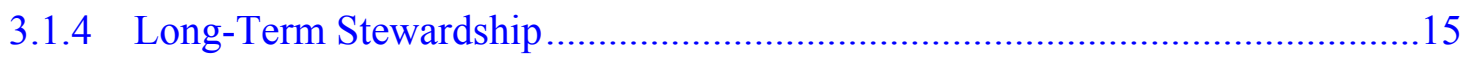

3.2 No Action Alternative ...............................................................................................

4.0 Affected Environment and Environmental Consequences ................................................. 15

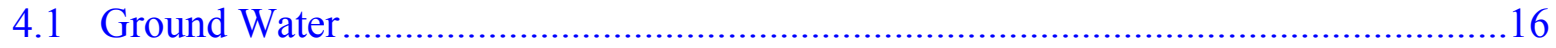

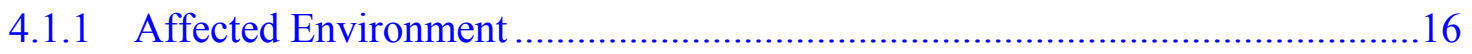

4.1.1.1 Alluvial Ground Water System............................................................16

4.1.1.2 Background Alluvial Ground Water Quality …………………….........17

4.1.1.3 Nature and Extent of Alluvial Ground Water Contamination ..............17

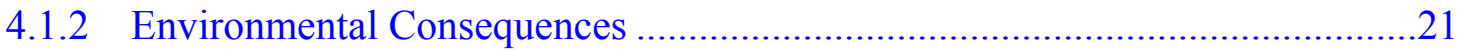

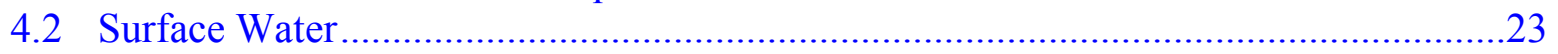

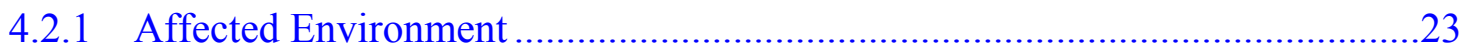

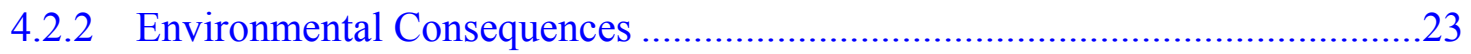

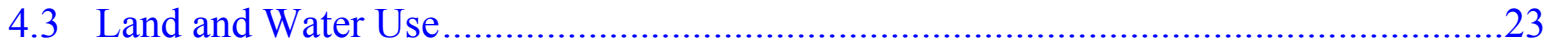

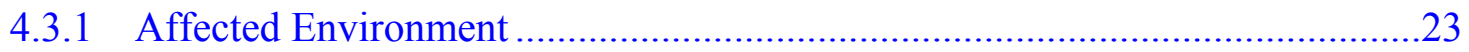

4.3.2 Environmental Consequences ..................................................................24

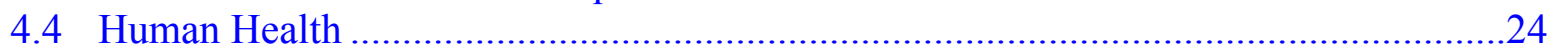

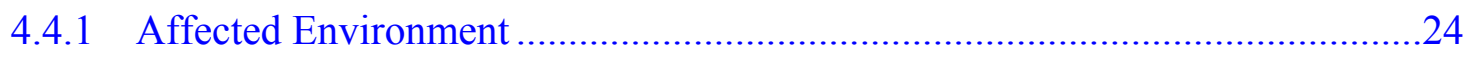

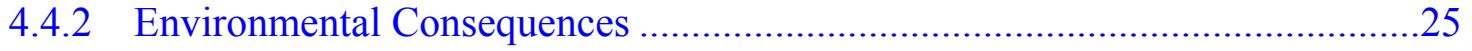

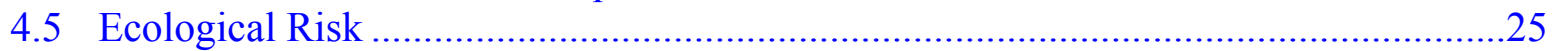

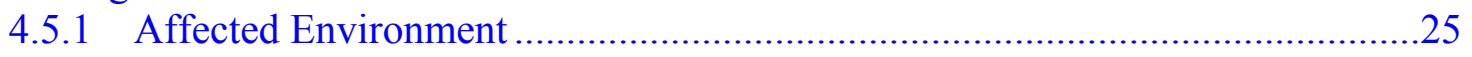

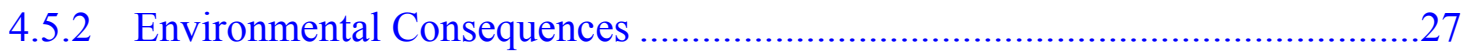

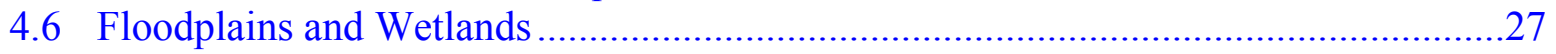

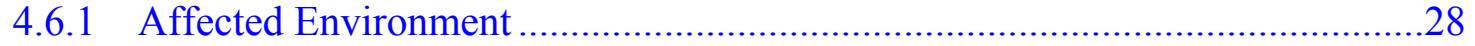

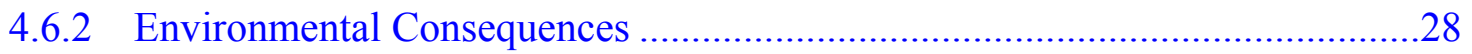

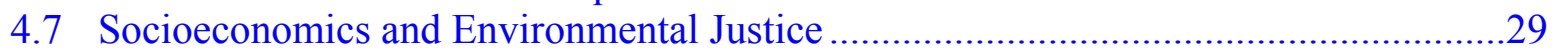

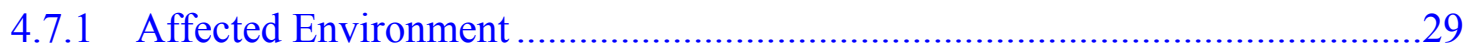

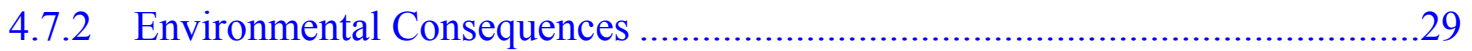

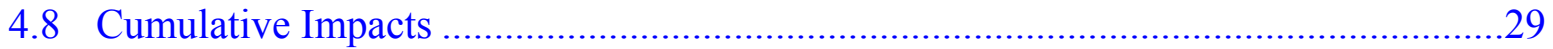


5.0 Persons and Agencies Consulted ........................................................................... 30

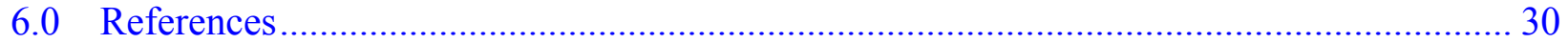

\section{Figures}

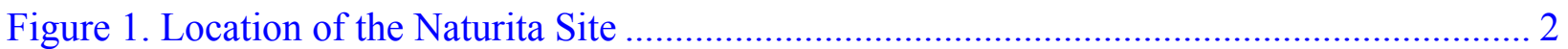

Figure 2. Land Status, Sampling Locations, and Immediate Actions at the Naturita Site............ 3

Figure 3. Supplemental Standards Areas at the Naturita Site .................................................. 5

Figure 4. Compliance Selection Framework for Uranium and Vanadium at the Naturita Site ...... 8

Figure 5. Proposed Monitoring Locations at the Naturita Site ........................................... 10

Figure 6. Institutional Controls Boundary ................................................................... 11

Figure 7. Time-Concentration Plot of Uranium in Alluvial Ground Water at the Naturita Site .. 14

Figure 8. Time-Concentration Plot of Vanadium in Alluvial Ground Water at the Naturita Site 15

Figure 9. Water Table Elevations and Contours at the Naturita Site....................................... 18

Figure 10. Uranium Concentrations at the Naturita Site; February 2002 Sampling Data ........... 20

Figure 11. Vanadium Concentrations at the Naturita Site; February 2002 Sampling Data......... 22

\section{Tables}

Table 1. Explanation of the Compliance Strategy Selection Process for Uranium and Vanadium

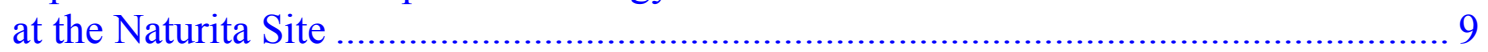

Table 2. Summary of Monitoring Requirements .............................................................. 12

Table 3. Alluvial Aquifer Contaminants of Potential Concern at the Naturita Site ................... 19

Table 4. Threatened or Endangered Species Likely To Occur at the Naturita Site..................... 26

\section{Attachment}

Attachment 1- Minutes of Public Meetings 


\section{Acronyms and Abbreviations}

CFR Code of Federal Regulations

DOE U.S. Department of Energy

EPA U.S. Environmental Protection Agency

$\mathrm{ft} \quad$ foot (feet)

MCL maximum concentration limit (listed in 40 CFR 192, Table 1 to Subpart A)

$\mathrm{mg} / \mathrm{L} \quad$ milligrams per liter

NEPA National Environmental Policy Act

PEIS Programmatic Environmental Impact Statement (for the UMTRA Ground Water Project)

SOWP Site Observational Work Plan

UMTRA Uranium Mill Tailings Remedial Action (Project)

$\mathrm{yd}^{3} \quad$ cubic yards 
This Page Intentionally Blank 


\section{Executive Summary}

This Environmental Assessment addresses the environmental effects of a proposed action and the no action alternative to comply with U.S. Environmental Protection Agency (EPA) ground water standards at the Naturita, Colorado, Uranium Mill Tailings Remedial Action Project site. In 1998, the U.S. Department of Energy (DOE) completed surface cleanup at the site and encapsulated the tailings in a disposal cell 15 miles northwest near the former town of Uravan, Colorado.

10 Ground water contaminants of potential concern at the Naturita site are uranium and vanadium. Uranium concentrations exceed the maximum concentration limit (MCL) of 0.044 milligram per liter (mg/L). Vanadium has no MCL; however, vanadium concentrations exceed the EPA Region III residential risk-based concentration of $0.33 \mathrm{mg} / \mathrm{L}$ (EPA 2002). The proposed compliance strategy for uranium and vanadium at the Naturita site is no further remediation in conjunction with the application of alternate concentration limits. Institutional controls with ground water and surface water monitoring will be implemented for these constituents as part of the compliance strategy. This compliance strategy will be protective of human health and the environment.

20 The proposed monitoring program will begin upon regulatory concurrence with the Ground Water Compliance Action Plan (DOE 2002a). Monitoring will consist of verifying that institutional controls remain in place, collecting ground water samples to verify that concentrations of uranium and vanadium are decreasing, and collecting surface water samples to verify that contaminant concentrations do not exceed a regulatory limit or risk-based

25 concentration. If these criteria are not met, DOE would reevaluate the proposed action and determine the need for further National Environmental Policy Act documentation.

No comments were received from the public during the public comment period. Two public meetings were held during this period. Minutes of these meetings are included as Attachment 1. 
This Page Intentionally Blank 


\subsection{Introduction}

The U.S. Department of Energy (DOE) removed residual radioactive materials from the former Naturita, Colorado, Uranium Mill Tailings Remedial Action (UMTRA) Processing Site and stabilized them offsite in an engineered repository under Title I of the Uranium Mill Tailings

5 Control Act. This brought the former processing site into compliance with U.S. Environmental Protection Agency (EPA) soil standards established under 40 Code of Federal Regulations (CFR) 192, Subparts A and C. Ground water contamination remaining at the site was characterized by DOE for the purpose of proposing a ground water compliance strategy. The proposed strategy is in compliance with EPA regulations in Title 40 Code of Federal Regulations

10 Part 192 (40 CFR 192). The regulations were established to minimize risk to human health and the environment that result from milling-related constituents in ground water. Maximum concentration limits (MCLs) referred to in this Environmental Assessment are the standards established in Title 40 Code of Federal Regulations Part 192 (40 CFR 192) unless noted otherwise.

\subsection{Site Description}

The Naturita UMTRA Project site is in western Colorado, Montrose County, approximately 2 miles north of the town of Naturita (Figure 1). The site encompasses 79 acres and is situated on an elongate northeast-southwest section of floodplain between Colorado State Highway 141 on the west and the San Miguel River on the east (Figure 2). This area is the location of a former vanadium and uranium mill that operated intermittently from 1939 until 1958.

\subsection{Site History}

Rare Metals Company built the Naturita vanadium mill around 1930. Rare Metals failed in the mid-1930s; however, Vanadium Corporation of America held the mortgage to the mill and reopened it in 1939 (Shumway 1970). The mill closed in 1958 when the contract with the U.S. Atomic Energy Commission, DOE's predecessor agency, expired. As early as 1950, milling-related contamination was detected in San Miguel River water downgradient of the site (Mogren 2002). In the fall of 1969, Foote Mineral, the owner, and the Colorado Department of Health tried to stabilize the tailings pile that was next to the San Miguel River by covering the pile with topsoil and seeding, fertilizing, and watering the surface to allow the grass to root. This was done in part because tailings were eroding from the site during flood periods of the San

35 Miguel River (DOI 1994). This stabilization effort was apparently unsuccessful, because a 1974 aerial photograph of the site shows exposed tailings. At that time, about 704,000 tons of tailings were located on the site (Ford, Bacon \& Davis Utah 1981).

By the 1970s, uranium was commercially viable, and in 1975, Foote Mineral leased a part of the millsite to the Nuclear Division of General Electric as a buying station for uranium ore. Operations continued into the 1980s. In 1976, Ranchers Exploration and Development Corporation bought 24 acres of tailings located on the site and removed an estimated 360,000 tons of tailings to a new location 4 miles to the southeast up Dry Creek for reprocessing. 


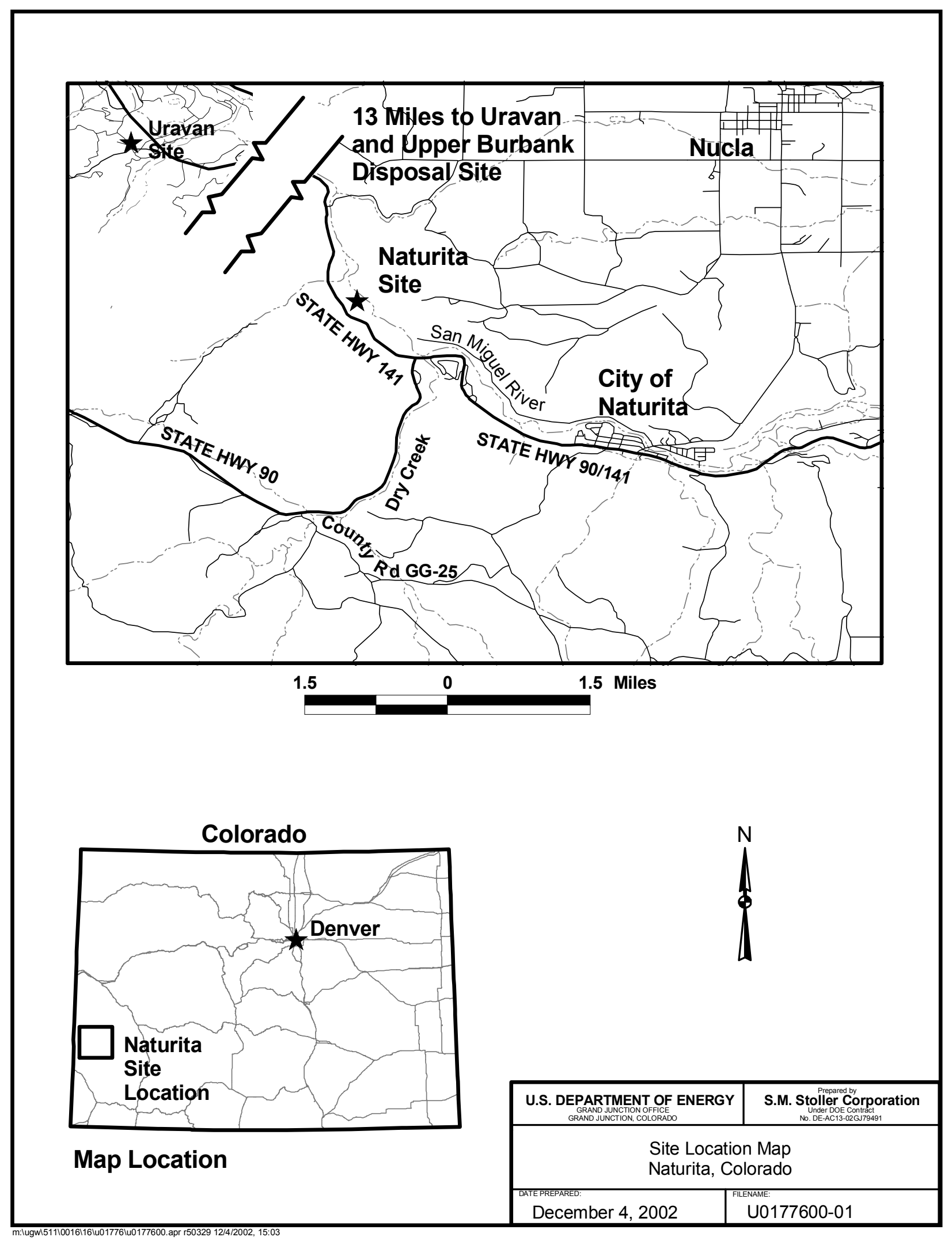

Figure 1. Location of the Naturita Site 


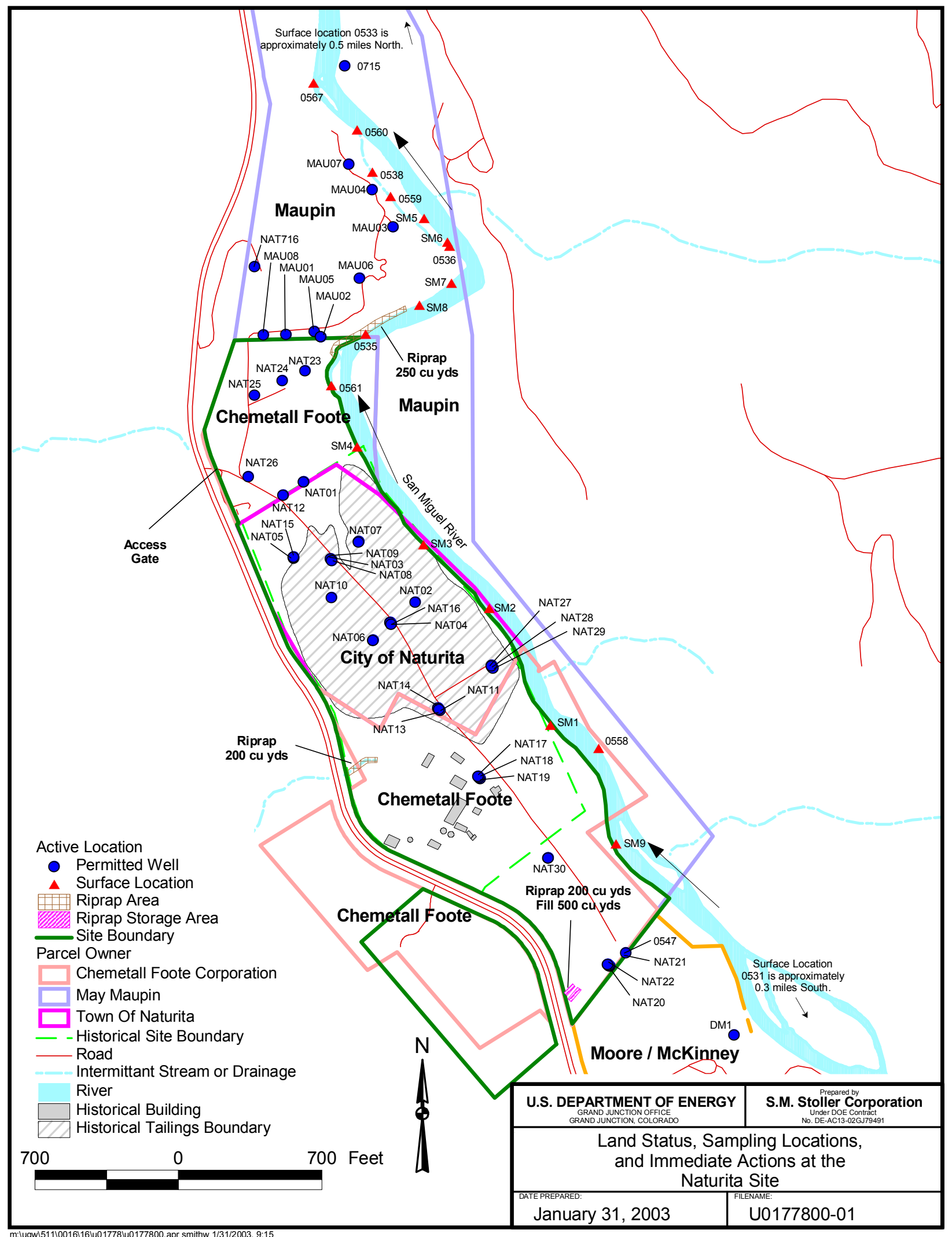

Figure 2. Land Status, Sampling Locations, and Immediate Actions at the Naturita Site 
From 1977 to 1979, Ranchers heap-leached the tailings and recovered an additional 380,000 pounds of uranium and 1,840,000 pounds of vanadium (DOI 1994). In 1978 Vanadium Corporation of America merged with Foote Mineral, and the downsizing of all former Vanadium Corporation of America operations accelerated. More recently, Foote Mineral was acquired by

The UMTRA Project surface remedial action at the site occurred between January 1993 and September 1998 (DOE 1998b). During this time, 771,400 cubic yards ( $\mathrm{yd}^{3}$ ) of residual radioactive materials was removed from the site. The approximate breakdown is $315,520 \mathrm{yd}^{3}$ from the former mill yard, $10,340 \mathrm{yd}^{3}$ from the former ore storage area, 209,880 $\mathrm{yd}^{3}$ from windblown areas, $225,490 \mathrm{yd}^{3}$ from the former tailings area, and 10,170 $\mathrm{yd}^{3}$ from stockpiled demolition debris. In addition, a contiguous vicinity property to the north (NT-65, the Maupin property) underwent remedial action, and 93,602 $\mathrm{yd}^{3}$ of material was removed (DOE 1998a). All material was hauled by truck to the Upper Burbank disposal cell about 15 miles to the northwest near the townsite of Uravan, Colorado. The former millsite was contoured and reseeded in 1998.

The Naturita site is unusual among UMTRA Project sites because of the large amount of residual radioactive materials left in place under supplemental standards, on site and off site, during surface remediation. Figure 3 shows the supplemental standards areas. The application of

20 supplemental standards during surface remediation was only permitted if the strategy was protective of human health and the environment and thus complied with EPA standards in 40 CFR 192 (DOE 1998b). Contamination was left in place in five areas totaling 11 acres on the site and another 11 acres on the adjacent downgradient vicinity property (Maupin property). Just over one acre of contaminated soil on the millsite was left in place because the radium-226

25 concentrations still exceeded the standard even though soil had been excavated to 1 foot (ft) below the water table. Other contaminated areas on the millsite and vicinity property were left in place because removing the material would produce excessive environmental harm and increased risk to workers who would have to remove it compared to the low radiological hazard. These areas were along the steep slopes of State Highway 141, near high-voltage power poles, and in 30 wetland areas adjacent to the San Miguel River.

Since 1999, and in response to requests from Montrose County and local residents, DOE took several actions to help further stabilize the site and adjacent vicinity property. DOE provided stockpiles of $200 \mathrm{yd}^{3}$ of riprap and $500 \mathrm{yd}^{3}$ of clean dirt to be used by the County in case the San

35 Miguel River floods the site during spring runoff or a storm event. Another action taken was to armor the riverbank with riprap along a stretch of the Maupin vicinity property to prevent future erosion and exposure of residual radioactive materials left on the property. This was considered important to protect monitor wells that may become flooded if the river overflowed its banks during spring runoff or storm events. A third action was to repair and armor an eroded culvert on the west side of the site that passes under Highway 141 and drains valleys to the west.

\subsection{Overview of Contamination}

Ground water contamination is a result of historical processing of uranium and vanadium ore at the site. A review of historical data collected during decommissioning and surface remediation indicated that additional analysis of ground water and surface water was needed to arrive at a remediation decision. DOE conducted these investigations, in conjunction with the United States Geological Survey, from 1998 to 2001. In May 2002, DOE completed the Site Observational 


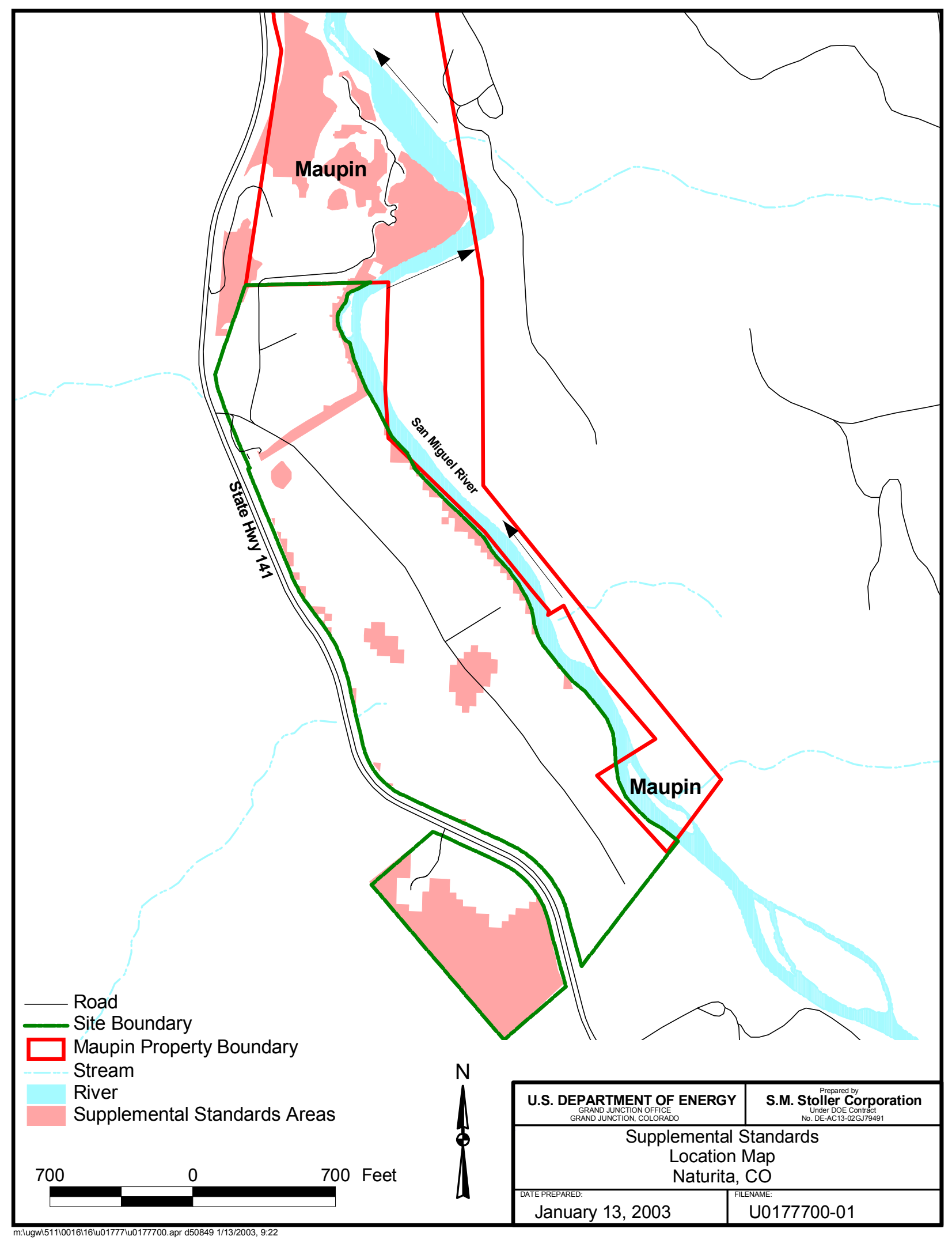

Figure 3. Supplemental Standards Areas at the Naturita Site 
Work Plan (SOWP) (DOE 2002b) that describes and analyzes the results of these investigations. All contaminants of potential concern listed in the Baseline Risk Assessment (DOE 1995) and other potential ecological risk constituents were evaluated. All but uranium and vanadium were determined to pose no unacceptable risks compared to established benchmarks at the Naturita site (DOE 2002b). Milling-related concentrations of these constituents are only in the uppermost aquifer, which consists of ground water in the unconsolidated surficial sediments in the valley. Uranium has been transported in ground water downgradient to the north and is in the alluvial aquifer beneath the vicinity property to the north. Because of its lower mobility, vanadium has not been transported as far downgradient as uranium, and the higher concentrations are generally confined to the area of the former tailings pile.

\subsection{Summary of Current Risk}

A Baseline Risk Assessment (DOE 1995) was prepared for the Naturita site using data collected from 1989 to 1994. Since that time, additional data were collected to characterize the human health and ecological risks more completely at the site and to represent more recent conditions. These new data were used to reevaluate the contaminants of potential concern and assess associated risks. A brief summary of this update is provided in the following two paragraphs. The detailed update to the Baseline Risk Assessment is presented in Section 6 of the SOWP

20 (DOE 2002b).

The human health risk assessment indicates that the only concern from uranium or vanadium to humans is through direct ingestion of alluvial ground water as drinking water in either an occupational or residential exposure scenario. The assessment suggests that institutional controls are needed to prevent the use of alluvial ground water as drinking water.

The recent evaluation of data indicates that the highest potential ecological risk is associated with exposure of aquatic life in the San Miguel River to barium. However, the source of barium is not considered to be site related because it was not associated with ores or chemicals used at the former millsite. Risks were also assessed as "medium" for exposure of wetland wildlife to vanadium in ground water discharging at a seep, assuming 100 percent of water intake occurs there. Vanadium concentrations in ground water beneath the floodplain exceed solution-based plant toxicity benchmarks and may pose some risk to phreatophytic plants (i.e., plants with roots in the water table) growing on the floodplain. All other risks calculated for complete exposure pathways were assessed as medium-low to none. Therefore, potential overall risk for nonsensitive species is not expected to be significant. Potential risk to the endangered southwestern willow flycatcher, for which potential habitat exists at the site, is considered to be very low, and is also not expected to be significant.

\subsection{National Environmental Policy Act Process}

The National Environmental Policy Act (NEPA) of 1969 requires federal agencies to analyze the environmental impacts of proposed and alternative actions. In 1996, DOE completed the Final Programmatic Environmental Impact Statement for the Uranium Mill Tailings Remedial Action

45 Ground Water Project (PEIS) (DOE 1996). In that document, DOE analyzed the potential effects of implementing the following alternatives for achieving ground water compliance at the UMTRA Project sites. A Record of Decision was issued in April 1997 in which DOE selected the Proposed Action Alternative for conducting the UMTRA Ground Water Project. Under the 
Proposed Action Alternative, DOE was given options of implementing (1) active ground water remediation, (2) passive ground water remediation, which includes natural flushing, (3) no ground water remediation, which includes sites that qualify for supplemental standards or alternate concentration limits, or sites where ground water contaminant concentrations do not exceed MCLs or background concentrations, or (4) any combination of these strategies.

The PEIS then recommended that DOE prepare site-specific NEPA documents, such as this Environmental Assessment for Naturita, to convey the strategy that was selected for each of the sites. The issues discussed and the environmental impacts analyzed in this Environmental Assessment are directly comparable to the PEIS as allowed by NEPA regulations in 10 CFR 1021.210(c).

\subsection{Purpose and Need for Action}

15 The purpose of the UMTRA Ground Water Project is to protect human health and the environment at abandoned uranium-ore processing sites by complying with the EPA ground water standards in 40 CFR 192. DOE proposes to implement the compliance strategy outlined in the Ground Water Compliance Action Plan (DOE 2002a), which uses the framework established in the PEIS (DOE 1996).

\subsection{Proposed Action and No Action Alternatives}

The PEIS provides several alternatives for complying with ground water standards in 40 CFR 192 and assesses the general effects associated with each alternative. DOE followed the

25 step-by-step decision process described in the PEIS to select the compliance strategy proposed in this Environmental Assessment. Section 3.1 describes the proposed action for the Naturita site and briefly describes the other alternatives DOE considered but eliminated. Section 3.2 describes the no action alternative, which is required to be evaluated in DOE's Environmental Assessments.

\subsection{Proposed Action Alternative}

\subsubsection{Decision Process for the Proposed Action}

35 DOE's proposed strategy at the site is no further remediation in conjunction with the application of alternate concentration limits for uranium and vanadium. Institutional controls and ground water and surface water monitoring will be implemented. Figure 4 shows the compliance selection framework, and Table 1 is a summary of the selection process. 


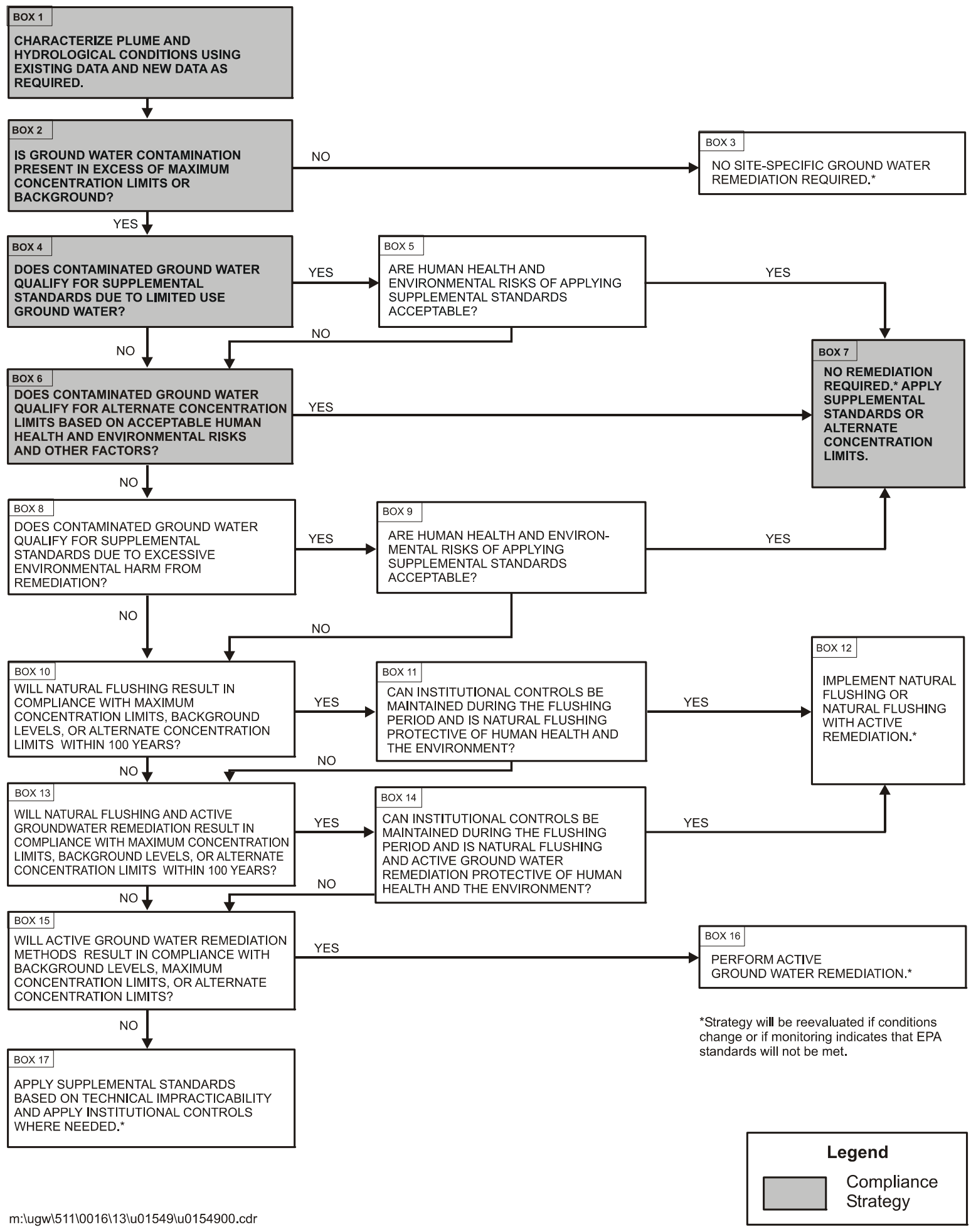

Figure 4. Compliance Selection Framework for Uranium and Vanadium at the Naturita Site 
Table 1. Explanation of the Compliance Strategy Selection Process for Uranium and Vanadium at the Naturita Site

\begin{tabular}{||c|l|l||}
\hline $\begin{array}{c}\text { Box } \\
\text { Figure 4 }\end{array}$ & \multicolumn{1}{|c|}{ Action or Question } & \multicolumn{1}{c||}{ Result of Decision } \\
\hline Box 1 & $\begin{array}{l}\text { Characterize plume and hydrological } \\
\text { conditions. }\end{array}$ & $\begin{array}{l}\text { See Site Conceptual Model in Section 5 of the SOWP } \\
\text { (DOE 2002b). Move to Box 2. }\end{array}$ \\
\hline Box 2 & $\begin{array}{l}\text { Is ground water contamination present in } \\
\text { excess of MCLs or background? }\end{array}$ & $\begin{array}{l}\text { Uranium concentrations exceed the MCL, and vanadium } \\
\text { concentrations exceed the risk-based concentration. } \\
\text { Move to Box 4. }\end{array}$ \\
\hline Box 4 & $\begin{array}{l}\text { Does contaminated ground water qualify } \\
\text { for supplemental standards due to a } \\
\text { classification of limited use ground water? }\end{array}$ & $\begin{array}{l}\text { Alluvial ground water does not meet any criteria for } \\
\text { limited use. Move to Box 6. }\end{array}$ \\
\hline Box 6 & $\begin{array}{l}\text { Does ground water qualify for alternate } \\
\text { concentration limits based on acceptable } \\
\text { human health and environmental risks } \\
\text { and other factors? }\end{array}$ & $\begin{array}{l}\text { Yes. No one is currently using the ground water for any } \\
\text { purpose. Institutional controls can be placed on affected } \\
\text { ground water to prohibit improper use in perpetuity. } \\
\text { Move to box 7. }\end{array}$ \\
\hline Box 7 & No further remediation required. & $\begin{array}{l}\text { Apply alternate concentration limits. Action levels are } \\
\text { 3 mg/L for uranium and 6 mg/L for vanadium at the point } \\
\text { of compliance. }\end{array}$ \\
\hline \hline
\end{tabular}

\section{$5 \quad$ 3.1.2 Explanation of the Proposed Action}

The proposed action consists of three parts: application of alternate concentration limits, institutional controls, and monitoring.

\subsubsection{Alternate Concentration Limits}

Alternate concentration limits are proposed for uranium and vanadium, the two contaminants of concern. The proposed limits are 3 milligrams per liter $(\mathrm{mg} / \mathrm{L})$ for uranium and $6 \mathrm{mg} / \mathrm{L}$ for vanadium as action levels at the point of compliance. These values are the approximate

15 maximum concentrations detected in ground water from the past few years. They are protective of human health because no complete exposure pathway exists. They are also protective of the environment because the concentrations decrease significantly as ground water discharges to and mixes with surface water of the San Miguel River.

20 The alternate concentration limits must be met at the points of compliance, which are considered to be all proposed long-term compliance wells in the monitoring network (Table 2 and Figure 5). Points of exposure are any points along the San Miguel River. These point-of-compliance concentrations would result in acceptable concentrations at the points of exposure along the San Miguel River. 


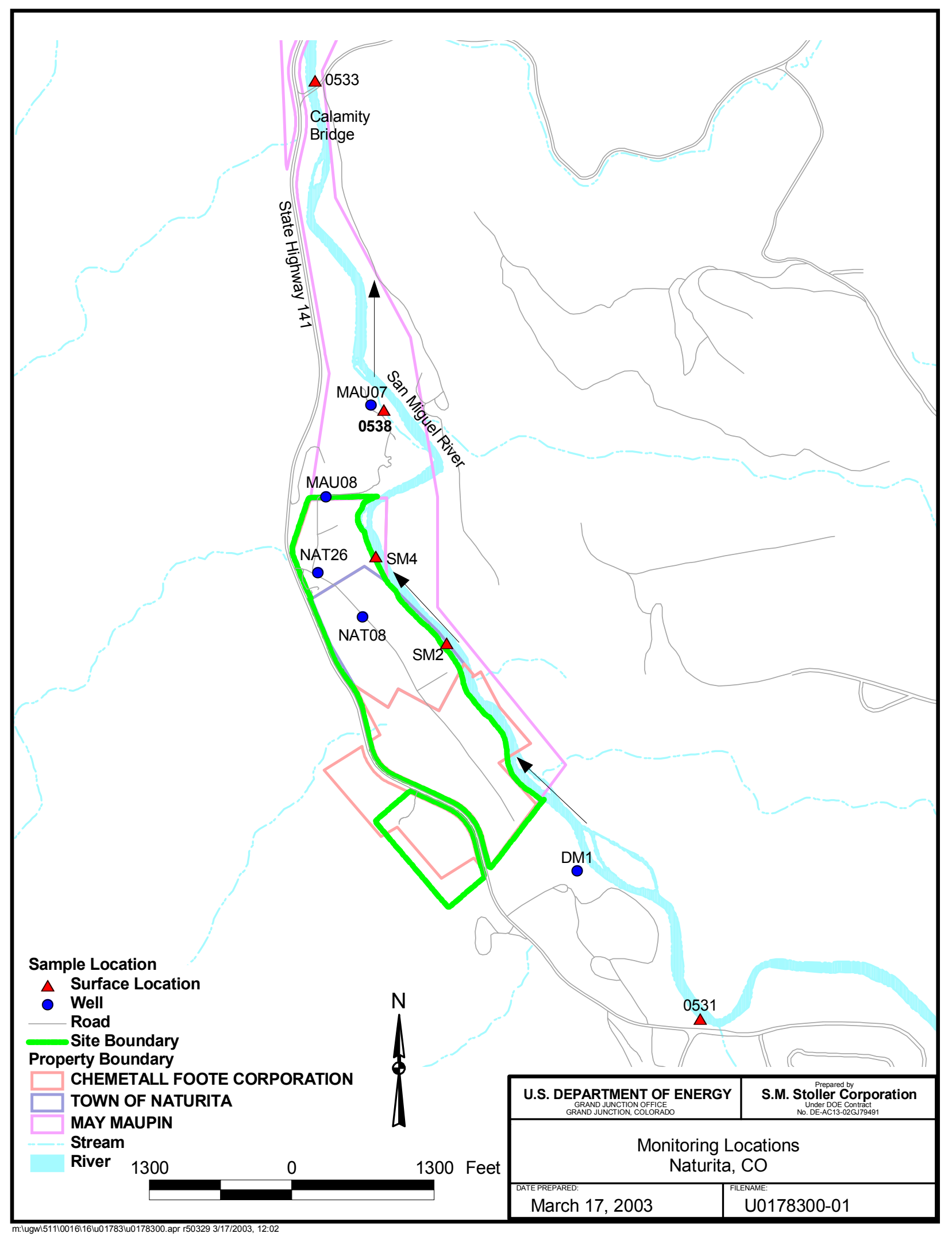

Figure 5. Proposed Monitoring Locations at the Naturita Site 


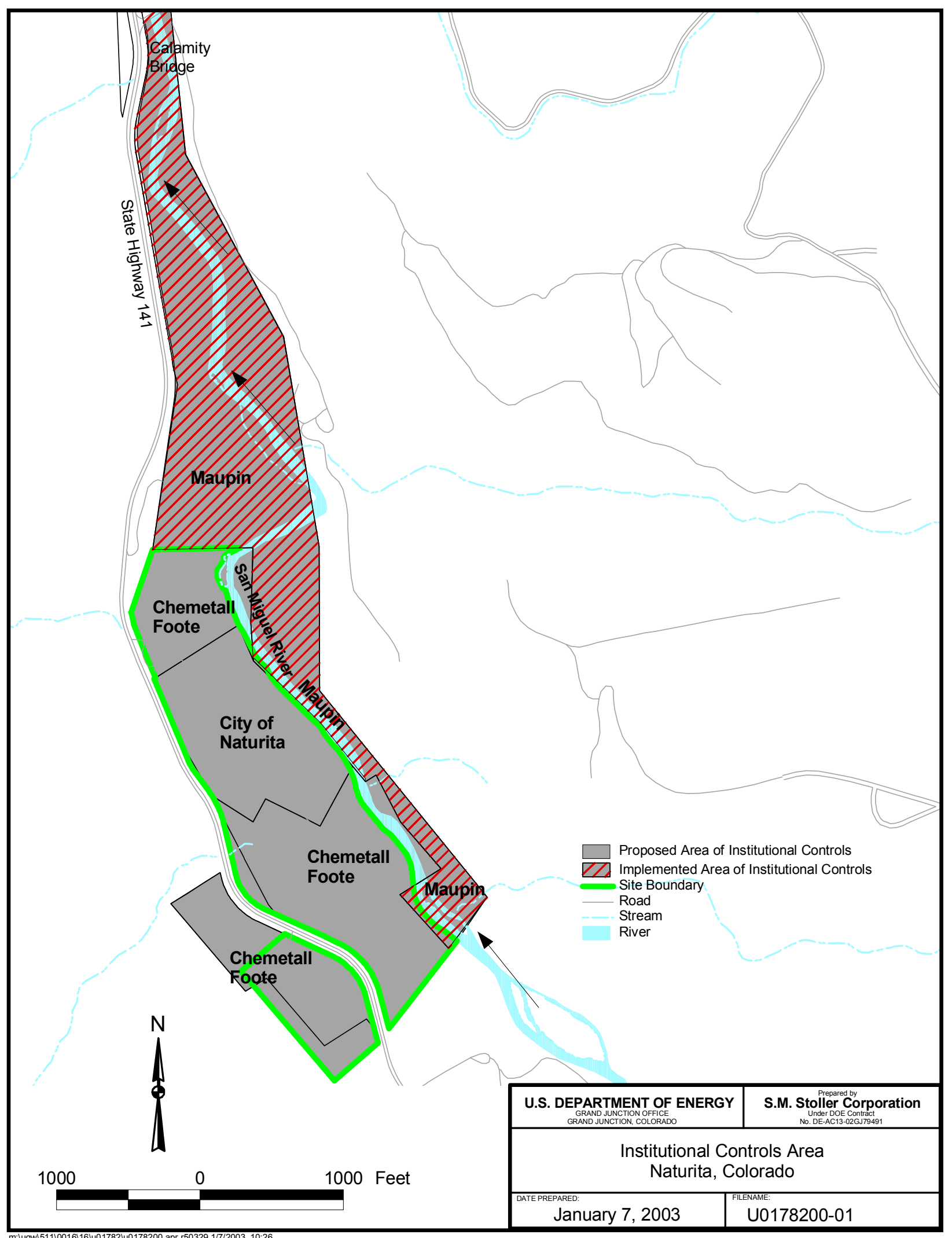

Figure 6. Institutional Controls Boundary 
Table 2. Summary of Monitoring Requirements

\begin{tabular}{|c|c|c|c|}
\hline Location & Monitoring Purpose & Analytes & Frequency \\
\hline Well DM1 & Background ground water & \multirow{10}{*}{$\begin{array}{l}\text { Uranium, vanadium, } \\
\text { total dissolved solids, } \\
\text { field parameters }\end{array}$} & \multirow{10}{*}{$\begin{array}{l}\text { Annually for } 5 \text { years; } \\
\text { afterwards every } 3 \text { years } \\
\text { for } 30 \text { years }\end{array}$} \\
\hline Well NAT08 & $\begin{array}{l}\text { Maximum vanadium concentration, point- } \\
\text { of-compliance well }\end{array}$ & & \\
\hline Well NAT26 & $\begin{array}{l}\text { Maximum uranium concentration, point-of- } \\
\text { compliance well }\end{array}$ & & \\
\hline Well MAU08 & Uranium plume, point-of-compliance well & & \\
\hline Well MAU07 & $\begin{array}{l}\text { Last well before ground water enters the } \\
\text { San Miguel River, point-of-compliance well }\end{array}$ & & \\
\hline Seep 0538 & $\begin{array}{l}\text { Elongate seep downgradient equals point- } \\
\text { of-compliance location }\end{array}$ & & \\
\hline Surface 0531 & $\begin{array}{l}\text { Upgradient San Miguel River point-of- } \\
\text { exposure location }\end{array}$ & & \\
\hline Surface 0533 & $\begin{array}{l}\text { Downgradient San Miguel River, } \\
\text { point-of-exposure location }\end{array}$ & & \\
\hline Surface SM2 & $\begin{array}{l}\text { Crossgradient from uranium plume, } \\
\text { point-of-exposure location }\end{array}$ & & \\
\hline Surface SM4 & $\begin{array}{l}\text { Crossgradient from vanadium plume, } \\
\text { point-of-exposure location }\end{array}$ & & \\
\hline
\end{tabular}

\subsubsection{Institutional Controls}

Chemetall Foote, the Town of Naturita, and the Maupin family own property affected by ground water contamination. The Maupin property is the only off-site property affected. Institutional controls would be placed on ground water that is currently contaminated or may be potentially affected in the future (Figure 6). Colorado Senate Bill 01-145, passed in July 2001, contains

10 provisions for creating perpetual environmental covenants that place restrictions on land use, including drilling and pumping of ground water from the land, where remedial actions have been completed and contamination has been left in place. The covenant is between the property owner and the State of Colorado. These covenants are legally enforceable restrictions on land use and therefore meet the definition of institutional controls under the Uranium Mill Tailings Radiation

15 Control Act (42 U.S. Code 7901 et seq.).

Such an environmental covenant would prohibit domestic use of contaminated ground water until monitoring indicates that contaminant concentrations are below regulatory limits. Figure 6 shows the total area to be covered by this type of institutional control. DOE, with assistance from

20 the Colorado Department of Public Health and Environment, is working with Chemetall Foote and the Town of Naturita to establish environmental covenants.

The Maupin family signed an environmental covenant with the Colorado Department of Public Health and Environment in July 2002, prohibiting the use of alluvial ground water for drinking

25 purposes. The covenant covers property extending along the floodplain on either side of the San Miguel River for approximately 3,600 ft downgradient of the site to the Calamity Bridge. In return, DOE provided a domestic water well to replace the beneficial use of ground water lost as a result of this institutional control. Figure 6 shows the area of the Maupin institutional control.

\subsubsection{Monitoring Plan}

Application and success of the proposed action would be verified through a monitoring program as required by $40 \mathrm{CFR} 192.12$ (c)(3). Continued monitoring would ensure that any exceedances of action levels would be detected early (Table 2). If exceedances are detected, DOE would 
reevaluate the proposed action and the need for additional NEPA documentation. Monitor wells DM1, NAT08, NAT26, MAU08, MAU07, and surface locations 0531, 0533, 0538, SM2, and SM4 would be monitored for uranium and vanadium (Figure 5). DM1 is a background ground water location; if it is removed by expansion of a nearby gravel mining operation, a suitable location would be selected for installation of a new background well.

Surface location 0531 is upgradient on the San Miguel River, 0533 is downgradient on the San Miguel River, and location 0538 is along a seep on the Maupin property. Location 0538 is considered a point-of-compliance location for ground water approaching the point-of-exposure along the San Miguel River. The location will be monitored for uranium, the only millsite contamination found here, with an action level of $0.30 \mathrm{mg} / \mathrm{L}$, slightly higher than the maximum concentration observed at the seep. Surface locations SM-2, crossgradient of the uranium plume, and SM-4, crossgradient of the vanadium plume, were added at the recommendation of Montrose County officials.

The proposed sampling frequency is once every year for the first 5 years following the U.S. Nuclear Regulatory Commission's concurrence with the Ground Water Compliance Action Plan (DOE 2002a). Thereafter, sampling would be conducted every 3 years for the next 30 years. At that time future risks and monitoring requirements would be reevaluated.

Institutional controls for the site will also be monitored. The Environmental Covenant legislation requires the landowner to provide annual compliance certification in the form of a letter to the State of Colorado. This will document annual performance for this agreement.

\subsubsection{Alternatives Considered but Eliminated}

Active remediation was considered but eliminated due to uncertainties about the ability to meet cleanup standards and the greater risk of performing remediation compared to the risk of leaving contaminated ground water in place. Vanadium is less mobile than uranium because it adsorbs more strongly to minerals, clays, and organic material in the aquifer. In addition, the limited ground water flow through the western part of the alluvial aquifer and the thinness of the aquifer would reduce the ability to pump water for treatment. Therefore, it is unlikely that an attempt to remove vanadium from the alluvial aquifer would be effective. Although uranium is more mobile, contamination in areas where tailings were left in place under surface supplemental standards would likely provide a long-term source of contamination. Figure 3 shows the supplemental standards areas. These areas would continue to adversely affect the success of any proposed ground water remediation.

DOE also considered the application of ground water supplemental standards for vanadium and 40 uranium; however, these constituents did not meet the regulatory criteria under 40 CFR 192.21. These criteria include the following:

- Total dissolved concentrations are at least $10,000 \mathrm{mg} / \mathrm{L}$.

- Widespread ambient contamination not due to ore-processing activities exists that cannot be cleaned up using treatment methods reasonably employed in public water systems.

- The quantity of water reasonably available for sustained continuous use is less than 150 gallons per day. 
Natural flushing is another process in which natural geochemical and biological processes and ground water movement decrease contaminant concentrations in the ground water through time.

The following conditions are requirements of the natural flushing compliance strategy (40 CFR 192.12[c][2]):

- Natural flushing must decrease concentrations of residual radioactive materials (i.e., mill-related contamination) to background levels, MCLs established in 40 CFR 192, or alternate concentration limits within 100 years.

- Institutional controls must be implemented that will effectively protect human health and the environment during the natural flushing period.

Figure 7 and Figure 8 show plots of time versus concentration for uranium and vanadium in four on-site wells monitored between November 1998 and May 2002. As the figures indicate, uranium concentrations are decreasing slowly but steadily, and vanadium concentrations show no significant decline during the monitoring period. Flow and transport modeling of uranium and vanadium indicates that these constituents will not flush to acceptable levels (background, MCLs, or health-based concentrations) during the 100-year natural flushing period. This in part is due to the persistence of uranium and vanadium in the soils from large areas of supplemental standards at the site that represent a potential long-term source of ground water contamination. It is probable that concentrations will decline slowly until soil and ground water interactions reach equilibrium; at that time ground water contaminant concentrations will probably level off. The time frame for this condition to occur is estimated to be greater than 100 years. Therefore, natural flushing was also dropped as an alternative.

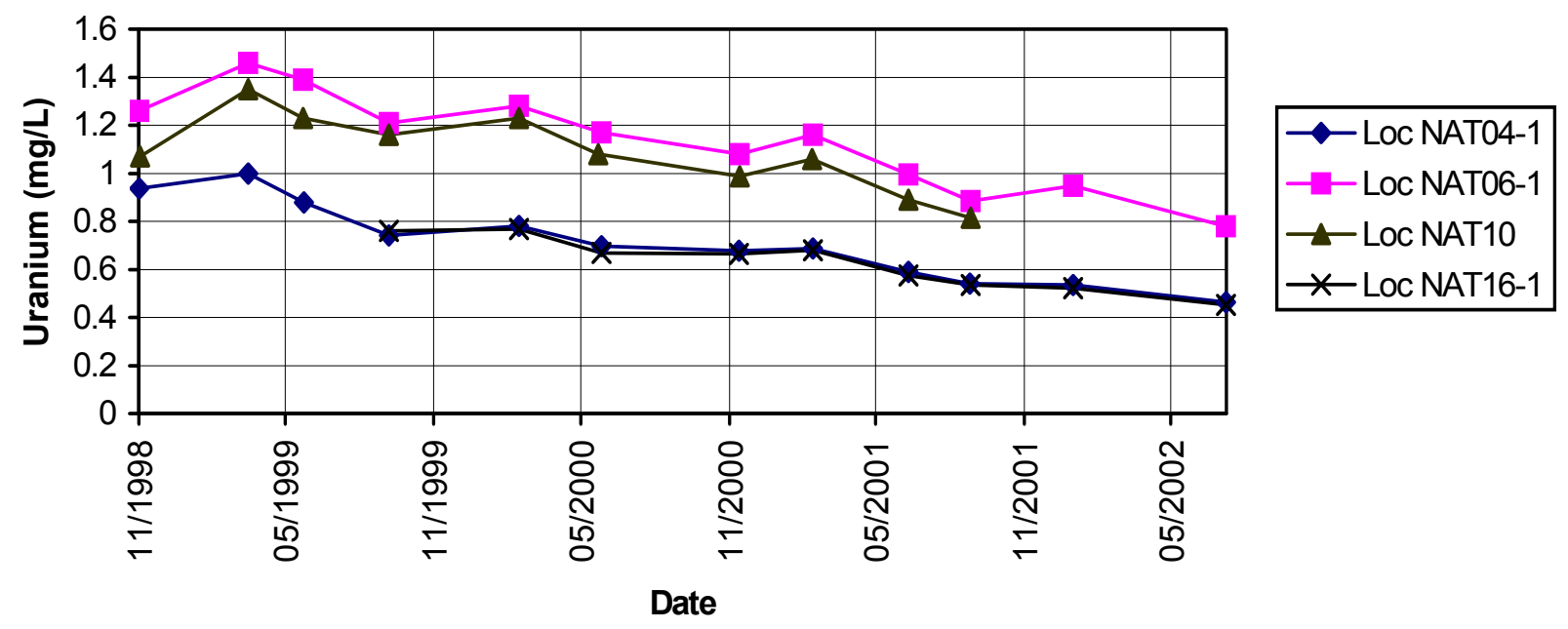

Figure 7. Time-Concentration Plot of Uranium in Alluvial Ground Water at the Naturita Site 


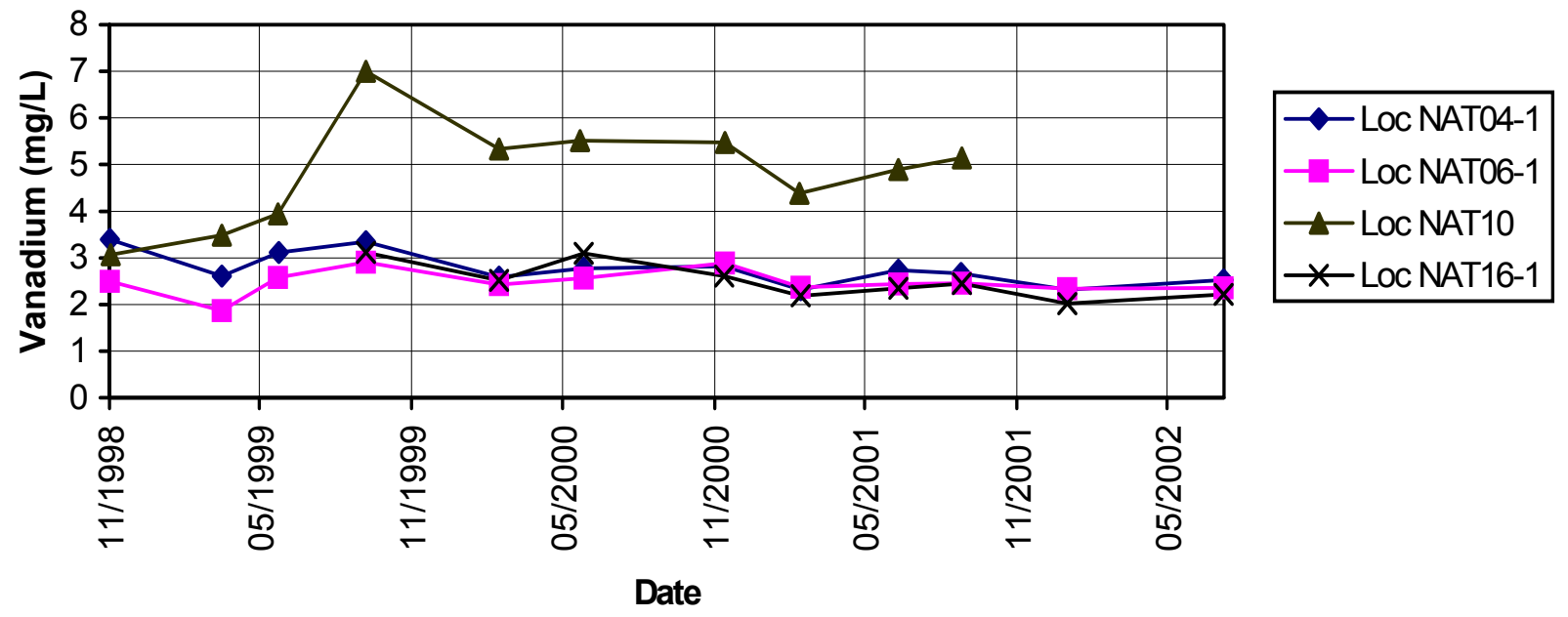

Figure 8. Time-Concentration Plot of Vanadium in Alluvial Ground Water at the Naturita Site

\subsubsection{Long-Term Stewardship}

Once the proposed action has been made final, DOE has the responsibility to ensure that the selected strategy continues to be protective of human health and the environment. Upon regulatory concurrence with the Ground Water Compliance Action Plan (DOE 2002a), the site would be turned over to the Long-Term Surveillance and Maintenance Program administered by the DOE Grand Junction Office in Grand Junction, Colorado. DOE will maintain authority and responsibility for long-term monitoring.

Long-Term Surveillance and Maintenance inspectors would periodically verify that ground water is not being used for any purpose and would ensure that the institutional controls are being enforced. Inspectors would look for indications of unauthorized use of ground water, such as drilling, building, and excavating and would take necessary legal and regulatory actions to enforce institutional controls.

\subsection{No Action Alternative}

DOE is required to evaluate a no action alternative in Environmental Assessments (10 CFR 1021.321[c]). Evaluation of a no action alternative provides a baseline for comparing the effects of the proposed action. Under the no action alternative for the Naturita site, DOE would conduct no further activities at the site and would conduct no monitoring of ground water

25 or surface water quality (DOE 1996). Although the natural flushing process would continue, DOE would not document compliance with ground water standards. No institutional controls would be implemented to prohibit access to and use of contaminated ground water.

\subsection{Affected Environment and Environmental Consequences}

30 NEPA guidance from DOE (DOE 1993) directs that only those environmental resource or issue categories that are relevant to the specific site need be addressed in proposed action or no action alternatives. These issues and resources are ground water, surface water, land and water use, human health, ecological risk, floodplains and wetlands, including threatened or endangered species, socioeconomics, and environmental justice. 
The following issues and resources are not affected and are therefore not addressed in this Environmental Assessment:

Resource or Issue

Air quality

Cultural and historical resources

Soils

Transportation

Visual resources

Wilderness areas, prime or unique farmlands, wild and scenic rivers

\section{Rationale}

No air emissions would result from the proposed action.

The proposed action would not involve any surface-disturbing activities; also, no cultural or historical resources are on or near the site.

No soils would be disturbed during the proposed action.

No increase in traffic would occur. The only transportation-related activity would be annual sampling at the monitoring locations.

No surface-disturbing activities would take place to affect visual resources.

None of these resources are at or near the site.

\subsection{Ground Water}

\subsubsection{Affected Environment}

\subsubsection{Alluvial Ground Water System}

The uppermost aquifer at the Naturita site is the alluvial aquifer and consists of the saturated portion of the valley sediments. It is the only aquifer of concern for ground water contamination because the underlying Brushy Basin Member of the Morrison Formation has an upward hydraulic gradient that prevents contaminants from migrating deeper. The alluvial aquifer is a wedge of sediment that varies in thickness from zero as it pinches out along the western bedrock to about $23 \mathrm{ft}$ along the San Miguel River near the northeastern portion of the site. It generally ranges from about 5 to $10 \mathrm{ft}$ in thickness over most of the site. The section of interest underlying the site is approximately 4,000 ft long and $700 \mathrm{ft}$ wide. Recharge and discharge occur along the length of the San Miguel River, depending on the river level. However, the primary recharge zone is thought to be a 600-ft strip from the San Miguel River about 2,400 $\mathrm{ft}$ south of the site near the confluence of Dry Creek, where the river makes a sharp bend. From there, water migrates slowly northwest through the aquifer until it finally exits back into the San Miguel

25 River north of the site along a 500-ft zone where the river intersects bedrock on the Maupin property. The aquifer pinches off against the San Miguel River at that point. Another source of water entering the alluvial aquifer is from arroyos draining from the west. Their significance is probably greater locally where intermittent water from these drainages could contribute to flushing contaminants in the aquifer near the western edge of the site. The last source of recharge is infiltration of rainfall. The Hopkins-Montrose airport in Nucla, 2.5 miles east of the site, receives approximately 11 inches of rain per year.

Hydraulic characteristics of the alluvial aquifer were determined by water age determinations, stable isotope and chloride measurements, falling-head slug tests, and bromide tracer tests.

35 Ground water age determination studies using tritium-helium and chlorofluorocarbon methods generally indicate increases in the age of water near the western side of the site. Flow paths are 
generally parallel to the San Miguel River, and older ages suggest slower flow rates along the western side of the site. This interpretation agrees well with the ground water surface contour map shown in Figure 9. Lines of equal elevations are generally perpendicular to the San Miguel River, and flow directions are perpendicular to the elevation contours. Discussion of the methods for determining ground water age and comparison of the ground water age estimates are in Section 5.3.4 of the SOWP (DOE 2002b).

The results of the age determinations agree with modeling results that show the "dogleg" portion of the aquifer in the northwestern part of the site has slower ground water flow rates than areas along the eastern side of the site. The open gravel pit on the Moore/Mckinney property (Figure 2) at the southern end and upgradient side of the site intersects ground water. Chloride and stable isotope studies suggest that this dewatering of the aquifer when water is pumped from the gravel pit will retard flow of ground water past this area and on the downgradient portion of the site. Falling-head slug tests were performed in 13 wells in November 1999 and May 2000.

15 This test measures how fast water percolates into the ground and provides an estimate of hydraulic conductivity. The hydraulic conductivity ranged from $19 \mathrm{ft} / \mathrm{day}$ (MAU04) to $333 \mathrm{ft} / \mathrm{day}$ (NAT09) and averaged $95 \mathrm{ft} /$ day. Bromide tracer tests were performed in six wells. In this test, bromide is injected into a well; and concentrations are measured through time at nearby downgradient wells. These results indicated hydraulic conductivities that ranged from $43 \mathrm{ft} / \mathrm{day}$ to $215 \mathrm{ft} /$ day. This is considered to be in fairly good agreement with the slug tests.

\subsubsection{Background Alluvial Ground Water Quality}

Background ground water quality is characterized by samples from background well DM1, 25 located in the alluvial aquifer upgradient from the former millsite (Table 5-2 of the SOWP, DOE 2002b). Background ground water quality at the Naturita site is generally good, with slightly high levels of sulfate and manganese. Sulfate concentration at background location DM1 exceeded the Colorado secondary drinking water standard of $250 \mathrm{mg} / \mathrm{L}$ in the November 2000 and March 2001 samples. Mean background concentrations of all other constituents are lower 30 than the MCLs in 40 CFR 192.

\subsubsection{Nature and Extent of Alluvial Ground Water Contamination}

Ground water sampling to monitor the nature and extent of ground water contamination at the

35 site has been conducted for the past 15 years. Results of sampling for the past two years are reported here. Figure 2 shows the locations of all the wells in the monitoring network.

Samples were collected from 28 wells (26 installed since 1998) and analyzed for constituents previously evaluated in the Baseline Risk Assessment (DOE 1995). All constituents except

40 two - uranium and vanadium - were removed as contaminants of potential concern for risk to human health and the environment. Table 3 shows the range and mean concentration for the contaminants. 


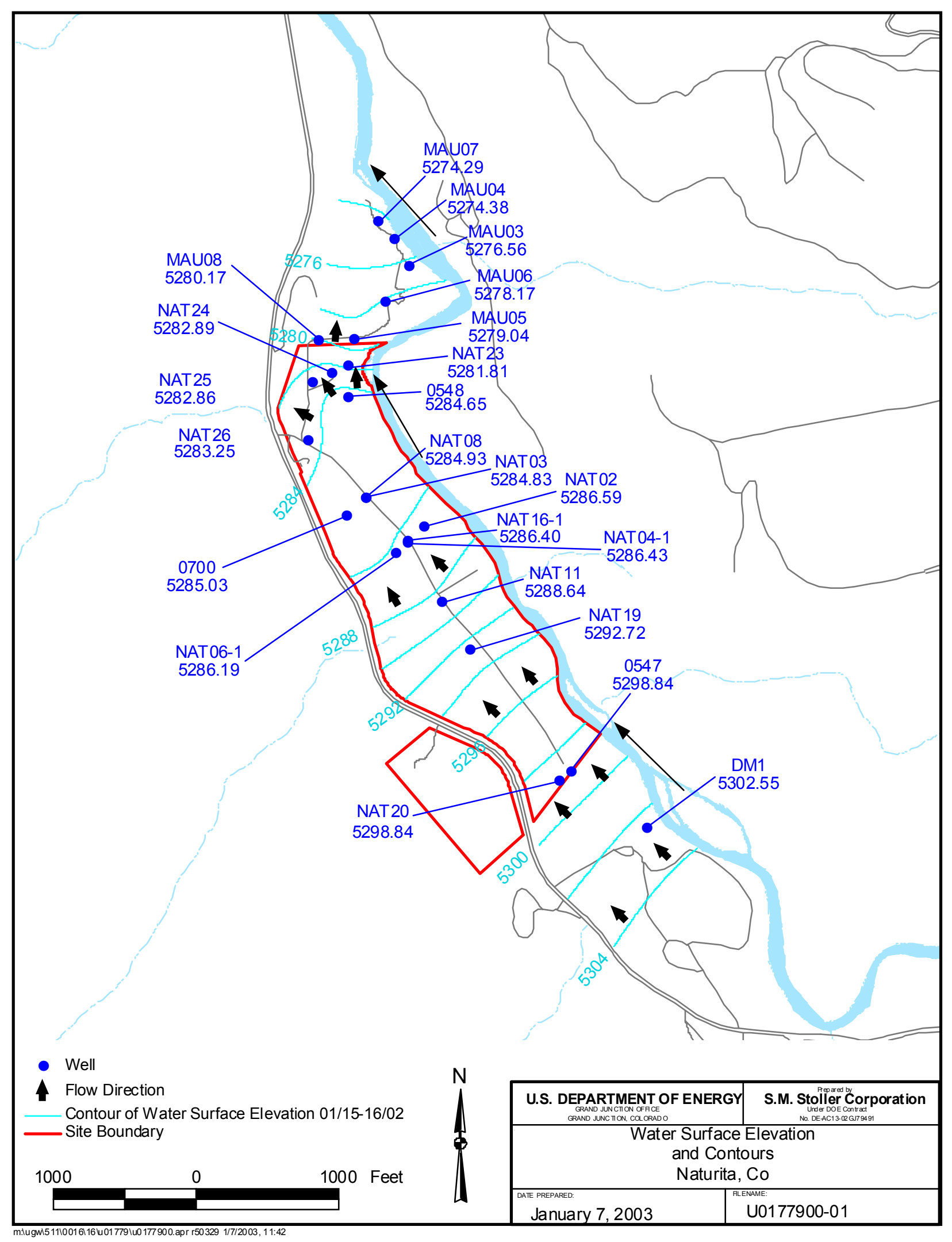

Figure 9. Water Table Elevations and Contours at the Naturita Site 


\section{Uranium}

Concentrations in ground water range from $0.0044 \mathrm{mg} / \mathrm{L}$ in well 0547 , located upgradient from the former tailings area, to $2.47 \mathrm{mg} / \mathrm{L}$ in well NAT26, located onsite slightly downgradient of the former tailings pile (Table 3). Concentrations of uranium from the most recent sample round are shown in Figure 10. Concentrations in all wells downgradient from well NAT30-1 exceed the MCL of $0.044 \mathrm{mg} / \mathrm{L}$. Well NAT30-1 is located near the upgradient edge of the former mill yard area. Uranium concentrations continue to be elevated as ground water moves downgradient under the former tailings area and into the adjoining downgradient vicinity property.

Table 3. Alluvial Aquifer Contaminants of Potential Concern at the Naturita Site

\begin{tabular}{|c|c|c|c|c|}
\hline Contaminant & $\begin{array}{c}\text { Frequency of } \\
\text { Detection }\end{array}$ & Range (mg/L) & Mean (mg/L) & $\begin{array}{c}\text { Point of Exposure } \\
\text { Concentrations } \\
\text { (mg/L) }\end{array}$ \\
\hline \multicolumn{4}{|l|}{ Uranium } & \multirow{3}{*}{0.044} \\
\hline Background & $10 / 10$ & $0.0029-0.0094$ & 0.0056 & \\
\hline Current plume & $103 / 103$ & $0.0044-2.470$ & 0.7030 & \\
\hline \multicolumn{4}{|l|}{ Vanadium } & \multirow{3}{*}{0.33} \\
\hline Background & $2 / 10$ & $0.00035-0.0004$ & 0.0004 & \\
\hline Current plume & $59 / 103$ & $0.00015-5.730$ & 1.1200 & \\
\hline
\end{tabular}

\section{Notes:}

Current plume wells: 0547,0548, 0700, MAU03, MAU05, MAU07, MAU08, NAT1-1, NAT02, NAT-03, NAT4-1, NAT6-1, NAT08, NAT10, NAT11, NAT15-1, NAT16-1, NAT19, NAT20, NAT23, NAT24, NAT25, NAT26, NAT27-1, NAT29, NAT30-1 Background well: DM-1

Current plume and background data were collected from fall 2000 through fall 2002.

Detection limits may vary due to sample dilution during analysis.

All measurements were performed on filtered samples.

20 The uranium value of $0.44 \mathrm{mg} / \mathrm{L}$ is the standard in $40 \mathrm{CFR} 192$, Table 1 to Subpart $\mathrm{A}$; the vanadium value of $0.33 \mathrm{mg} / \mathrm{L}$ is the EPA Region III risk-based concentration (EPA 2002).

Point of Exposure Concentrations are not expected to ever be met in the San Miguel River because of mixing of ground water with river water; should they be met or exceeded, corrective action would be implemented.

25 Concentrations decrease at the northern or downgradient end of the site near the bend in the San Miguel River. Ground water age determinations and flow modeling suggest that water in wells MAU06, MAU03, and MAU04 is a combination of older ground water flowing from the south that is mixing with younger San Miguel River water. Well MAU07, with a higher concentration of uranium, may represent a component of contaminated water from the site that has flowed

30 closer to the western side of the floodplain and has not been diluted as much by river water. Wells MAU06, MAU03, MAU04, and MAU07 and surface location 0538 all have uranium concentrations that are significantly greater than that of the San Miguel River, indicating contamination is most likely millsite related. Surface location 0538 is a ground water seep that collects in a small area near the river and periodically desiccates, producing elevated concentrations of metals. River water flushes this location during high water.

Another possible influence on the uranium distribution on the downgradient vicinity property is secondary leaching of tailings deposited during flood stages over the past half century. Aerial photographs from the 1950s and 1960s indicate that a series of San Miguel River channels once crossed the eastern side of the vicinity property before the current east-bending dogleg in the channel was established. During flood stages, tailings could have been eroded from the former tailings pile and deposited in low-lying channels in this region. If the tailings were in contact with ground water, metals could have leached into the ground water and produced elevated concentrations of uranium. 


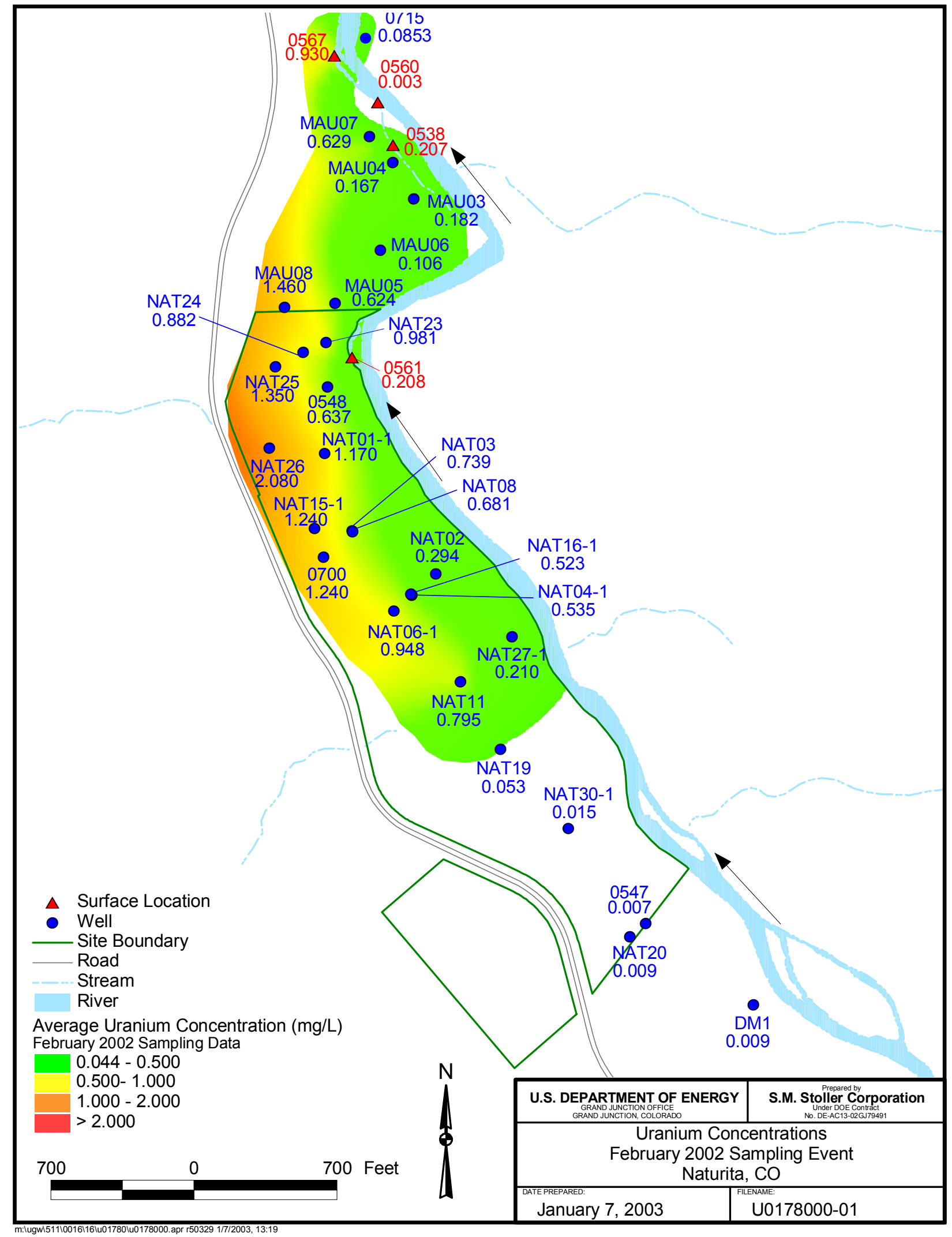

Figure 10. Uranium Concentrations at the Naturita Site; February 2002 Sampling Data 
An alluvial monitor well was installed and sampled in April 2002, on the east side of the San Miguel River slightly downgradient of the contamination on the west side of the river. The purpose was to determine if contamination existed on the east side of the river. The April 2002 sample contained $0.080 \mathrm{mg} / \mathrm{L}$ uranium, which is about twice the MCL and probably represents millsite contamination. Two explanations could account for the contamination. The first is the historical deposition of millsite tailings during river flooding and the subsequent leaching of these tailings. Or, the uranium plume may have traveled beneath the San Miguel River into the floodplain on the east side of the river. In either case, institutional controls will prohibit the use of this ground water.

\section{Vanadium}

Concentrations range from below the detection limit $(<0.0001 \mathrm{mg} / \mathrm{L})$ to a maximum value of $5.73 \mathrm{mg} / \mathrm{L}$ in well NAT08 (Table 3). Figure 11 shows the most recent distribution of vanadium

15 concentrations in the February 2002 sample round. Because of its lower mobility, vanadium has not been transported as far downgradient as uranium, and the higher concentrations are generally confined to the area of the former tailings pile (shown on Figure 2).

\subsubsection{Environmental Consequences}

\section{Proposed Action Alternative}

Flow and transport modeling predicts that neither uranium nor vanadium will naturally flush to the MCL or risk-based concentration of $0.044 \mathrm{mg} / \mathrm{L}$ and $0.33 \mathrm{mg} / \mathrm{L}$, respectively, within

25100 years. Alternate concentration limits of $3 \mathrm{mg} / \mathrm{L}$ for uranium and $6 \mathrm{mg} / \mathrm{L}$ for vanadium are proposed as action levels at the points of compliance, which are considered to be all wells on site. These values are approximately the maximum concentrations currently detected in monitor wells on site. Action level concentrations may be proposed in the area of maximum contamination if it can be demonstrated that human health and the environment are protected at

30 any point of exposure, that is any location where ground water surfaces and becomes available to receptors. Points of exposure are any places along the San Miguel River where a person or organism could contact surface water that is, in part, recharged by ground water. Measurements of ground water contaminants downgradient of the maximum concentrations and toward the San Miguel River indicate that contaminant levels decrease as they mover closer to the river.

35 Conservative calculations of ground water discharging into the San Juan River and mixing with river water indicate that concentrations of ground water contaminants in the river will rapidly decrease to insignificant levels, far below all applicable standards.

\section{No Action Alternative}

The no action alternative would also allow ground water contaminated with uranium and vanadium to slowly flush into the San Miguel River. However, unlike the proposed action, natural attenuation processes would continue and no institutional controls would be in place to prevent access to contaminated ground water. Wells could potentially be drilled into the

45 contaminated ground water and humans or animals could have access to the water. No monitoring would occur, and the quality of the ground water through time would be unknown. No actions to mitigate possible exposures to humans or the environment would occur. 


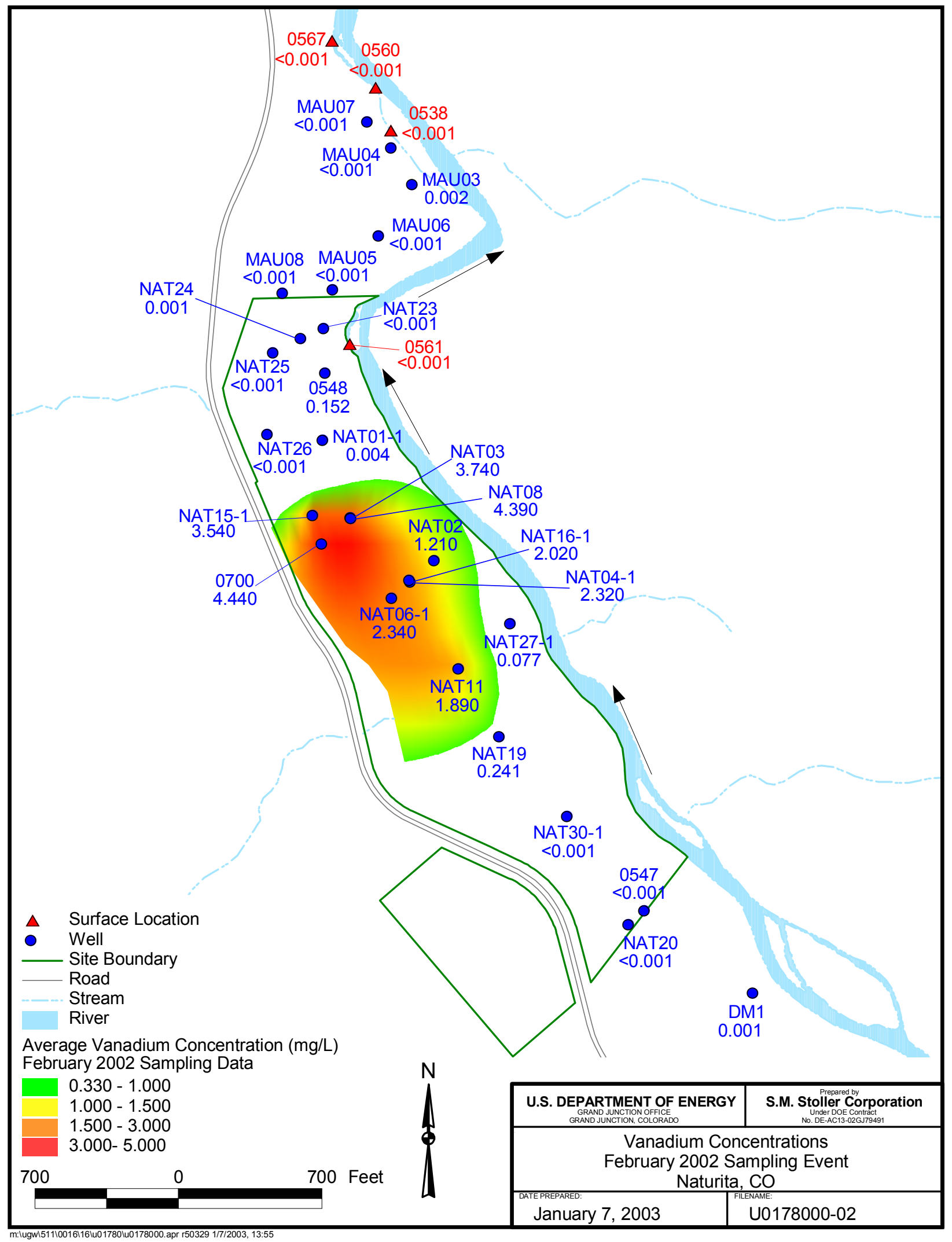

Figure 11. Vanadium Concentrations at the Naturita Site; February 2002 Sampling Data 


\subsection{Surface Water}

\subsubsection{Affected Environment}

5 The only permanent surface water features at the Naturita site are the San Miguel River and a ground water seep that originates at location 0538 and feeds a small pond along the former distributary channel. Ground water discharges to the San Miguel River. Calculations have shown that even at low river flow, contaminant concentrations in ground water discharging to the river are reduced by a factor of 4,000 or more and have no measurable effect on river water quality

10 (DOE 1995). Mill-related contamination has not been detected in the river. Concentrations of some constituents in water discharging from the seep are elevated and are further concentrated through evaporation during drier months. However, the ecological and human health risk assessments indicated that exposure of potential receptors to these waters would not result in an unacceptable risk (see SOWP Section 6.2)

\subsubsection{Environmental Consequences}

\section{Proposed Action Alternative}

20 Surface water monitoring has indicated that the proposed strategy of no remediation with alternate concentration limits would be protective of the water quality in the San Miguel River. The scenario of insignificant impact to the river would not be expected to change as the uranium and vanadium plumes move toward and flush into the river. Monitoring of the San Miguel River will continue to verify that the strategy is protective of human health and the environment.

\section{No Action Alternative}

The San Miguel River would not be adversely affected under the no action alternative. As with the proposed action alternative, contaminants in the ground water that flow into the river will

30 decrease over time, and monitoring has shown that the volume of water in the river naturally decreases contaminant concentrations as it enters the river. However, there would be no monitoring to verify that excess concentrations do not appear in the river.

\subsection{Land and Water Use}

\subsubsection{Affected Environment}

\section{Land Use}

40 The entire site is in private or municipal ownership (Figure 9). Currently, the parcels owned by the Town of Naturita and Chemetall Foote are fenced and are not being used. The Town has expressed interest in obtaining the property owned by Chemetall Foote for eventual development of a golf course. DOE and the State are working to facilitate this transfer. The Maupin family owns property adjacent to and downgradient of the site and uses the area for grazing. A gravel pit is being operated upgradient of the site. The area is also grazed by wildlife. 


\section{Ground Water Use}

Ground water is not currently being used at the site. A domestic well drilled by DOE into the Entrada Sandstone for the Maupin family is cased and grouted into $42.5 \mathrm{ft}$ of the Brushy Basin Member of the Morrison Formation. Previous hydrologic tests from the site show an upward hydraulic gradient in both the Morrison Formation and the underlying Entrada Formation. The well was screened from 585 to $545 \mathrm{ft}$ below ground surface and grouted to the surface; the water level in the well is within $80 \mathrm{ft}$ of the surface.

\section{Surface Water Use}

Currently, surface water in the area where ground water discharges to the river is not used for domestic purposes. The Maupin family pumps river water for irrigation. Livestock and wildlife drink from the river.

\subsubsection{Environmental Consequences}

\section{Proposed Action Alternative}

20 Site-related contaminants are not adversely affecting San Miguel River water quality. Therefore, use of river water for irrigation or as a source of drinking water for livestock and wildlife would not be affected. DOE would continue to monitor surface water to verify that water quality is not being adversely affected.

\section{No Action Alternative}

The San Miguel River would not be adversely affected under the no action alternative. As with the proposed action alternative, concentrations of ground water contaminants that flow into the river would decrease over time. Monitoring has shown that the volume of river water naturally

30 decreases contaminant concentrations as ground water mixes with river water. However, there would be no monitoring to verify that excess concentrations do not appear in the river.

\subsection{Human Health}

\section{$35 \quad$ 4.4.1 Affected Environment}

Alluvial ground water at the Naturita site does not currently pose a health risk to humans because it is not being used for any purpose. The only potentially complete exposure pathway to contaminated ground water is where it discharges to the San Miguel River or to seeps on the Maupin property. 


\subsubsection{Environmental Consequences}

\section{Proposed Action Alternative}

5 Under the proposed action, institutional controls would ensure that contaminated ground water is not used for any purpose and would be protective of human health. DOE would continue to monitor ground water and surface water for uranium and vanadium at the locations shown in Figure 5. Wells not needed for the monitoring network would be decommissioned in accordance with UMTRA Project procedures and applicable State of Colorado regulations. Standard

10 procedures are in place to ensure that activities associated with decommissioning and monitoring activities are protective of workers.

The only complete exposure pathway to ground water contamination is by contact where contaminated water discharges to the San Miguel River and to seeps on the Maupin property. In

15 the river, ground water mixes with river water, and contaminant concentrations decrease significantly and are protective for any likely human exposures to surface water. Monitoring of surface water quality would continue in order to ensure protectiveness of human health for probable uses. Risks were calculated for dermal exposure, water ingestion, and sediment ingestion for several exposure scenarios as part of the risk assessment update in the SOWP

20 (DOE 2002b). None of these exposure scenarios resulted in unacceptable risks as measured by established benchmarks and standards.

\section{No Action Alternative}

25 Under the no action alternative, no further activities would take place at the Naturita site. Institutional controls would not be applied, and monitoring would be discontinued. Flushing of contaminant levels would probably continue, but the rates at which this occurs would not be evaluated. Because of the lack of institutional controls, contaminated water could be used for unsuitable purposes and could present unacceptable risks.

\subsection{Ecological Risk}

\subsubsection{Affected Environment}

35 A baseline inventory of wildlife species likely to inhabit the site area was documented in the Environmental Assessment of Remedial Action at the Naturita Uranium Processing Site Near Naturita, Colorado (Surface EA, DOE 1994), based on investigations of flora and fauna between 1986 and 1994. The Surface EA assessed the effects of surface remediation for both sensitive and nonsensitive species and described potential ecological receptors, including threatened or

40 endangered species.

\section{Habitat}

Three major community (or habitat) types are dominant in the millsite area: piñon-juniper

45 woodland, sagebrush-grass community, and a riparian community along the San Miguel River. Except for the riparian habitat along the river, surrounding habitats are generally characterized as semiarid and are influenced by the low to moderate annual precipitation. Tamarisk, cottonwood, willow, alder, and birch dominate the riparian habitat. Most of the riparian areas in the millsite area 
are currently used as pasture for livestock (primarily horses). However, the area is also known to provide winter range for large mammals, including deer and elk. Drinking water sources such as the San Miguel River and tributaries are available in or near these habitats and add to their attractiveness to wildlife. A seep at location 0538 provides a small pond and criteria wetland of approximately one acre at the northeast end of the site. It is likely that amphibians, primarily frogs, inhabit this pond. This area is thought to be the most downgradient extent of contamination and was the primary focus of ecological assessment in the SOWP.

\section{Nonsensitive Species}

Nineteen to 26 species of mammals may occur in the vicinity of the site. Terrestrial wildlife such as foxes, coyotes, skunks, raccoons, deer, and rodents likely use the riparian habitats for foraging, resting, denning, and other activities. Seventy-eight species of birds have been recorded at or near the site. Birds of the riparian habitats include resident and migratory species (e.g., bald eagle).

15 Waterfowl, such as ducks and geese, use the aquatic habitat of the San Miguel River. The river is also suitable habitat for cold-water game fish, primarily various trout species. Limited sampling conducted to support the Surface EA showed that the flannelmouth sucker and rainbow trout were the most common fish species. The surface EA also indicated that at least 11 species of reptiles and amphibians inhabit the riparian area near the site, and an additional 14 species inhabit the

20 upland areas.

\section{Sensitive Species}

Consultations with the U.S. Fish and Wildlife Service during completion of the surface EA

25 indicated that six federally listed species, one federally proposed species, and nine candidate species that may occur in the vicinity of the site. Of these, only two, the bald eagle (Haliaeetus leucocephalus) and the southwestern willow flycatcher (Empidonax traillii extimus), which has been listed since the Surface EA was completed, are of concern (Table 4). The bald eagle has been sighted in the area; however, no nesting sites have been confirmed. Potentially suitable

30 habitat for the flycatcher exists (located on private land); however, no birds were observed or heard during surveys conducted from 1990 through 1994.

Table 4. Threatened or Endangered Species Likely To Occur at the Naturita Site

\begin{tabular}{||l|c|c|c|l||}
\hline \multicolumn{1}{||c|}{ Species } & $\begin{array}{c}\text { Federal } \\
\text { Status }\end{array}$ & $\begin{array}{c}\text { Critical } \\
\text { Habitat }\end{array}$ & $\begin{array}{c}\text { State } \\
\text { Status }\end{array}$ & Comments \\
\hline Birds & $\mathrm{T}$ & $\mathrm{N}$ & $\mathrm{T}$ & $\begin{array}{l}\text { Marginal potential for nesting sites. No } \\
\text { known sites near area. }\end{array}$ \\
\hline $\begin{array}{l}\text { Bald eagle (Haliaeetus } \\
\text { leucocephalus) }\end{array}$ & $\mathrm{E}$ & $\mathrm{N}$ & $\mathrm{E}$ & $\begin{array}{l}\text { Potentially suitable habitat exists in the } \\
\text { general vicinity of the site on private } \\
\text { land. }\end{array}$ \\
\hline $\begin{array}{l}\text { Southwestern willow flycatcher } \\
\text { (Empidomax traillii extimus) }\end{array}$ &
\end{tabular}

andangered Species Act listed; $\mathrm{T}=$ threatened, $\mathrm{E}=$ endangered

${ }^{\mathrm{b}}$ Designated critical habitat, $\mathrm{N}=\mathrm{No}$

No additional surveys or consultations have occurred since 1994, primarily because land subject to ground water regulations is privately owned, and land use is at the discretion of the landowner. DOE will determine the need for additional consultation once comments from this environmental assessment have been received from affected landowners, the U.S. Fish and Wildlife Service, and the public. 


\subsubsection{Environmental Consequences}

\section{Proposed Action Alternative}

5 The risk assessment process is outlined in EPA guidance documents, particularly in Guidelines for Ecological Risk Assessment (EPA 1998), which expands upon and replaces the earlier Framework for Ecological Risk Assessment (EPA 1992). The ecological risk assessment conducted as part of the Baseline Risk Assessment and its update in the SOWP (DOE 2002b) generally follow these documents. Ecological contaminants of potential concern in ground water and surface water are addressed in Section 6.2 of the SOWP.

DOE collected samples of ground water, surface water, and sediments to determine if contaminants were present in those media that may pose a risk to wildlife. In order for a risk to be present, a medium must have contaminant concentrations that exceed background

15 concentrations, a complete exposure pathway to a receptor must exist, and the contaminant concentrations present must have reasonable potential to present an adverse effect as measured by established benchmarks or standards. Contaminated soils were removed from all areas except the supplemental standards areas during surface remediation.

20 To evaluate potential risk, hypotheses were developed for the Naturita site where complete exposure pathways to ecological receptors may exist based on the current site conditions. Section 6.2 of the SOWP (DOE 2002b) discusses the risk hypotheses in detail. On the basis of risk characterization (SOWP Section 6.2.5), potential risk to ecological receptors, including sensitive species is considered low to very low. Receptors included aquatic organisms, benthic

25 organisms, upland plants, wetland plants, terrestrial wildlife (including birds), livestock, and wetland wildlife.

Because institutional controls would restrict access to ground water, contaminated ground water would not be brought to the surface, where it could provide a potentially complete exposure

30 pathway to wildlife. However, vanadium in ground water may pose a low risk to phreatophytic plants (i.e., plants with roots in the water table) growing in the floodplain.

\section{No Action Alternative}

35 DOE would not implement institutional controls to prohibit access to contaminated ground water, which could conceivably be pumped to the surface and stored in a tank or pond, where livestock and wildlife could consume it.

\subsection{Floodplains and Wetlands}

A floodplain/wetlands assessment was completed in 1994 for the Surface EA (DOE 1994) that included detailed descriptions of the affected plant communities. Surface remediation removed vegetation from the floodplain, and it was also widened, which changed the reach of the 100 -year floodwaters. 


\subsubsection{Affected Environment}

\section{Floodplain}

5 The 100-year floodplain was enlarged slightly by surface remediation and includes 38 acres of the former millsite. During a 100-year flood event, this area would be inundated to an average depth of $5 \mathrm{ft}$. Peak flow for the 100-year flood was developed using the U.S. Army Corps of Engineers HEC-2 software (USACE 1982). The 100-year flow would be 10,800 cubic feet per second based on the U.S. Geological Survey gauging station on the San Miguel River at Naturita.

A sparse cover of crested wheatgrass (Agropyron cristatum) is the dominant vegetation on the floodplain, along with some weeds, including kochia (Kochia scoparia) and cheatgrass (Bromus tectorum). Horses graze on the floodplain.

\section{Wetlands}

Four riparian/wetland vegetation types are on the Naturita site. Detailed descriptions of the original wetlands are included in the floodplain/wetlands assessment prepared for the Surface EA (DOE 1994). The wetlands were not substantially affected by the surface remedial action. Then

20 and now they consist of a strip of riparian and wetland vegetation along the San Miguel River, dominated by willows and cottonwoods, and an area of about one acre near location 0538 (Figure 2). Some tamarisk and willows grow along a ditch through the north end of the site. Because supplemental standards were applied to the wetlands, the 1995 remediation did not affect these areas.

A willow-dominated riparian area begins at the north end of the site along the river. Sandbar willow (Salix exigua) up to $8 \mathrm{ft}$ tall is the main species, with an understory of smooth brome (Bromus inermis), thistle (Cirsium sp.), common reed (Phragmites australis), Wood's rose (Rosa woodsii), and aster species.

The south end of the riparian area has two distinct vegetation types. One type is an abundance of mature lanceleaf cottonwoods (Populus accuminata), with an herbaceous understory of scratchgrass muhly (Muhlenbergia asperifolia) and sweet clover (Melilotus officinalis). The other is a mixture of willows and cottonwoods, both juvenile and mature, with a variety of

35 grasses and forbs underneath.

The final wetland vegetation area is a 10-ft-wide strip along a ditch toward the north end of the site. It is mostly 6- to 8-ft-tall sandbar willow and some Canada thistle (Cirsium arvense), tamarisk (Tamarix), and common reed (Phragmites australis).

\subsubsection{Environmental Consequences}

\section{Proposed Action Alternative}

45 The proposed action would have no effect on floodplains and wetlands at the site. There has been no apparent effect of ground water contamination on these areas, and no surface disturbance is proposed. 


\section{No Action Alternative}

The no action alternative would also have no effect on the floodplain or wetlands.

\section{$5 \quad 4.7$ Socioeconomics and Environmental Justice}

\subsubsection{Affected Environment}

Executive Order 12898, Federal Actions to Address Environmental Justice in Minority

10 Populations and Low-Income Populations, states that federal programs and actions shall not disproportionately affect minority or low-income populations. The 2000 census in Naturita found that 10.3 percent of the population is Hispanic or Latino, 6.5 percent is Native American, and 2.2 percent is other minorities.

\section{$15 \quad$ 4.7.2 Environmental Consequences}

\section{Proposed Action Alternative}

Ground water at the site is not a current or potential source of drinking water, and institutional

20 controls would prevent unauthorized access to the contaminated ground water. Therefore, no adverse effects to any populations would be expected.

\section{No Action Alternative}

25 No disproportionately high or adverse effects to minority or low-income populations would occur under the no action alternative. However, no institutional controls would be implemented and future residents could have access to contaminated ground water.

\subsection{Cumulative Impacts}

The Council on Environmental Quality defines "cumulative impact" as the "impact on the environment which results from the incremental impact of the action when added to other past, present, and reasonably foreseeable future actions regardless of what agency or person undertakes such other actions" (40 CFR 1508.7). The former Naturita millsite is the only

35 UMTRA facility contributing contamination to the San Miguel River. Another former uranium/vanadium millsite, which remained corporately owned, is located 15 miles downstream at Uravan, Colorado. It has undergone surface remedial action and is currently undergoing active ground water remedial action.

40 Institutional controls for the former Naturita millsite would prohibit activities that potentially entailed use of or exposure to contaminated ground water. Therefore, no cumulative impacts are anticipated as a result of the proposed action. The no action alternative would not prohibit access to contaminated ground water, which could conceivably be pumped to the surface and consumed by humans or wildlife. 


\subsection{Persons and Agencies Consulted}

Montrose County Commissioners and Montrose County Engineer, Montrose, Colorado

Mayor of Naturita, Naturita, Colorado

U.S. Army Corps of Engineers, Montrose, Colorado

$5 \quad$ U.S. Fish and Wildlife Service, Grand Junction, Colorado

Colorado Department of Public Health and Environment, Denver, Colorado

Colorado Attorney General's Office, Denver, Colorado

Chemetall Foote, Steve Hooper, Kings Mountain, North Carolina

Maupin Family, Naturita, Colorado

10 Bill Payne, Payne and Associates, Inc., Englewood, Colorado

Moe Pasha, EMC ${ }^{2}$, Golden, Colorado

Bureau of Land Management, Montrose Office, Colorado

U.S. Geological Survey, Dave Naftz, Salt Lake City, Utah, and

Jim Davis, Menlo Park, California

15 Doc Moore, Naturita, Colorado

\subsection{References}

10 CFR 1021. U.S. Department of Energy, "National Environmental Policy Act Implementing

20 Procedures," Code of Federal Regulations, January 1, 2001.

40 CFR 192. U.S. Environmental Protection Agency, "Health and Environmental Protection

Standards for Uranium and Thorium Mill Tailings," Code of Federal Regulations, July 1, 2001.

2540 CFR 1508.7. Council on Environmental Quality, "Cumulative Impact," Code of Federal Regulations, July 1, 2002.

42 U.S.C. $\$ 7901$ et seq. "Uranium Mill Tailings Radiation Control Act," United States Code, November 8, 1978.

Ford, Bacon \& Davis Utah, 1981. Naturita Site, Naturita, Colorado, Engineering Assessment of Inactive Uranium Mill Tailings, prepared for U.S. Department of Energy Albuquerque Operations Office, Albuquerque, New Mexico.

35 Mogren, E.W., 2002. Warm Sands Uranium Mill Tailings Policy in the Atomic West. University of New Mexico Press, Albuquerque, New Mexico.

Shumway, G.L, 1970. A History of the Uranium Industry on the Colorado Plateau, PhD. Dissertation, University of Southern California, Los Angeles, California.

U.S. Army Corps of Engineers (USACE), 1982. HEC-2 Water Surface Profile User's Manual, computer program 723-X6-L202A, Water Resources Support Center, The Hydrologic Engineering Center, Davis, California. 
U.S. Department of Energy (DOE), 1993. Recommendations for the Preparation of Environmental Assessments and Environmental Impact Statements, Office of NEPA Oversight, May.

- 1994. Environmental Assessment of Remedial Action at the Naturita Uranium Processing Site Near Naturita, Colorado, DOE/EA-0464, U.S. Department of Energy Albuquerque Operations Office, Albuquerque, New Mexico.

_ 1995. Baseline Risk Assessment of Ground Water Contamination at the Uranium Mill Tailings Site near Naturita, Colorado, DOE/AL/62350-195, Rev. 1, U.S. Department of Energy, Albuquerque Operations Office, Albuquerque, New Mexico.

- 1996. Final Programmatic Environmental Impact Statement for the Uranium Mill Tailings Remedial Action Ground Water Project, DOE/EIS-0198, U.S. Department of Energy, 15 UMTRA project Office, Albuquerque Operations Office, Albuquerque, New Mexico, October.

— 1998a. Naturita, Colorado UMTRA Final Completion Report, U.S. Department of Energy, Albuquerque Operations Office, Albuquerque, New Mexico.

$20 \longrightarrow$ 1998b. Remedial Action Plan for the Inactive Uranium Processing Site at Naturita, Colorado, DOE/AL/62350-249, Rev. 0, U.S. Department of Energy, Albuquerque Operations Office, Albuquerque, New Mexico.

U.S. Department of Energy (DOE), 2002a. Ground Water Compliance Action Plan for the 25 Naturita, Colorado, UMTRA Project Site, GJO-GWNAT 1.9, U.S. Department of Energy Grand Junction Office, Grand Junction, Colorado, September.

_ 2002b. Site Observational Work Plan for the Naturita, Colorado, UMTRA Project Site, MAC-GWNAT 1.1, U.S. Department of Energy Grand Junction Office, Grand Junction,

30 Colorado, May.

U.S. Department of the Interior (DOI), National Park Service, 1994. "Vanadium Corporation of America (VCA) Naturita Mill," a Historic American Engineering Record, prepared by Carl McWilliams and Lisa Schoch-Roberts of Cultural Resource Historians, Fort Collins, 35 Colorado.

U.S. Environmental Protection Agency (EPA), 1992. Framework for Ecological Risk Assessment, EPA/630/R-92/001, Risk Assessment Forum, Washington, D.C.

$40 \longrightarrow$, 1998. Guidelines for Ecological Risk Assessment, EPA/630/R-95/002F, Risk Assessment Forum, Washington, D.C.

— 2002. Risk-Based Concentration Table, U.S. EPA Region III, updated October 9, 2002, available on the Internet at www.epa.gov/reg3hwmd/risk/index.htm. 


\section{End of current text}

EA of Ground Water Compliance at the Naturita Site

DOE Grand Junction Office

Page 32

April 2003 


\section{Attachment 1}

\section{Minutes of Public Meetings}


This page intentionally left blank 


\section{Minutes for the Public Meeting held in Nucla, Colorado, March 12, 2002 to discuss the Environmental Assessment of Ground Water Compliance at the Naturita, Colorado, UMTRA Project Site}

5 Meeting was held at the Nucla Town Hall, 320 Main Street, Nucla, Colorado, on March 12, beginning at 10:30 am, in conjunction with the Montrose County Commissioner's meeting. Approximately 17 people attended including County Commissioners, the County Engineer, and a representative of Chemetall Foote - a landowner. See attached attendance sheet.

10 Don Metzler, DOE-GJO, made a presentation about the history of the site, surface cleanup with supplemental standards applications, former and recent characterization, interpretation of these results regarding local geology, ground water flow, contaminants, and flow and transport modeling results. The proposed compliance strategy of no remediation required with the application of alternate concentration limits for uranium and vanadium was discussed.

During the presentation, several questions were asked and comments made. Other questions were asked after the presentation.

Leo Large (Montrose County Commissioner) asked about when the land transfer might occur.

20 He indicated that a mechanism called the environment covenant that is a new state code is being used for limiting liability to landowners and will be most helpful in concluding the land transfer. He had been on a conference call regarding this issue with Colorado Department of Public Health and Environment (CDPHE) and Chemetall Foote personnel. Don Metzler had also been on a similar conference call and indicated that if all actions continued in the direction they

25 currently were, the property could be transferred as early as this summer to the local government. Mr. Metzler also indicated that an old document between the landowners and DOE called the Remedial Action Agreement was being terminated. It was left over from the surface program and was no longer needed.

30 Leo Large and others wanted to know if Chemetall Foote had water rights from the San Miguel River with their property? The answer to this question was unknown, but would be investigated by the Chemetall Foote representative (Moe Pasha), who was in attendance.

The commissioners did not voice any objections to the compliance strategy and mainly wanted to

35 know when the Chemetall Foote property could be transferred to the local government.

Ms. Pat Smith asked if an environmental covenant could be established for her upgradient vicinity property that had undergone surface remediation? This action would be addressed by a representative of CDPHE who would be available later that day. Ms. Smith was visited by that

40 representative later in the day and the matter was undertaken by that office.

Doc and Nancy Moore also were possibly interested in an environmental covenant for their vicinity property, which adjoins the millsite on the upgradient side. They had also undergone surface remediation. CDPHE will also contact them.

Brian Wilson requested that color patterns, representing concentrations of contaminants, from the modeling could be replicated on plume maps. This was agreed. 
Mr. Metzler closed by indicating that he was most pleased to be before this group and appreciated their time. The period for public comment would continue through March 24 . With no further discussion and unless other issues were raised, he now thought DOE had a clear path forward to complete this EA and NEPA process.

The DOE portion of the meeting concluded at 11:30 am. 


\section{Minutes for the Public Meeting held at Naturita, Colorado, March 12, 2002, to discuss the Environmental Assessment of Ground Water Compliance at the Naturita, Colorado, UMTRA Project Site}

5 Meeting was held at the Naturita Community Building, 411 West $2^{\text {nd }}$ Street, in Naturita and started at 6:00 pm. Fifteen people attended including representatives of the Colorado Department of Public Health and Environment, the Mayor, a County Commissioner, other city officials, and a representative of Chemetall Foote - a landowner. See attached sign-in sheet.

10 Don Metzler, DOE-GJO, made a presentation about the history of the site, surface cleanup with supplemental standards applications, former and recent characterization, interpretation of these results regarding local geology, ground water flow, contaminants, and flow and transport modeling results. A proposed compliance strategy of no remediation required with the application of alternate concentration limits for uranium and vanadium was discussed. $\mathrm{Mr}$.

15 Metzler also discussed the transfer of two sections of the site from Chemetall Foote to the local government. If all actions continue favorably, the transfer could occur as early as this summer.

During the presentation, several questions were asked and comments were made. The discussion continued after the presentation.

The following are questions/answers and comments from attendees.

Q. Steve Phare - Were radiological surveys done for the surface program for the supplemental standards areas and could he get a copy of them.

A. Radiological surveys were done and supplemental standards applications were based on those results. The results would be in the Completion Report, which is available in the local library (Leo Large mentioned this).

Q. Steve Phare - Has DOE sampled fish and birds around the site for the risk assessment?

A. DOE did not do any additional sampling for fish or birds near the site for this characterization effort. DOE did not think it was needed for this site because of the lack of contamination signature in the San Miguel River. Metzler mentioned the Warm Sand book that indicated that the river had shown contamination 50 years ago, but has cleaned itself up since then. At the Riverton site in Wyoming, DOE did sample fish that were living in an oxbow lake downgradient of the former millsite. Another attendee mentioned that Ranchers had found 1\% uranium in the pile when they moved it in the 1970s.

Q. Can horses and cattle graze on the former millsite?

A. Yes. Clean fill was used as cover for the site, as for all sites.

Comment. Leo Large spoke about the Environmental Covenant that would be used as the mechanism for limiting liability to former landowners. This would help in the easing the minds of Chemetall Foote and should help facilitate the transfer. The covenant would also prevent the use of wells for anything other than monitoring.

Comment. Steve Phare stressed that the local town was most interested in acquiring the Chemetall Foote sections of the former millsite and that hopefully the water rights along the San Miguel River would go along with it. Mr. Large agreed. 
Ms. Pat Smith of East Vancorum requested that DOE sample her pond, upgradient of the site, the next time we sampled. DOE agreed to do this.

The Library requested a copy of the presentation. It will be sent.

5

Mr. Metzler closed by indicating that he was most pleased with the participation from this group and mentioned that the period for public comment would be through March 24. He now thought DOE had a clear path forward to complete this EA.

10 The meeting concluded at 7:00 pm. 